\title{
Lietuvių švietimo draugija „Rytas“ 1939-1940 m.
}

\begin{abstract}
Straipsnyje, remiantis pirmąsyk plačiai nagrinèjama archyvine medžiaga, apžvelgiamas paskutinis Lietuvių švietimo draugijos „Rytas“ laikotarpis (1939-1940): nurodomas naujų narių skaičius, pateikiami duomenys apie steigiamas skaityklas, organizuojamus naujus skyrius, aptariama kita draugijos veikla. Detalizuojami akivaizdūs lenkų valdžios bandymai riboti „Ryto" veiklą jau nuo 1936 m., tai tęsèsi iki 1938 m.: 1938 m. sausio 29 d. „Ryto" veikla buvo sustabdyta, o 1938 m. vasario 28 d. Vilniaus vaivada „Ryto" draugiją uždarè. „Ryto“ draugijos veikèjų pastangomis (tam buvo palanki ir politinè situacija) $1939 \mathrm{~m}$. gegužès $20 \mathrm{~d}$. Vilniaus vaivadija draugiją atkūrè, o birželio $6 \mathrm{~d}$. (nors ir su didelëmis skolomis) perduotas draugijai priklausęs turtas. Draugija „Rytas“ (nepaisant naujų trukdžių, intensyviai veikusi nuo 1939 m.), kaip ir kitos katalikiškos organizacijos, sovietinès valdžios buvo uždaryta $1940 \mathrm{~m}$.

On the basis of the archival materials extensively explored for the first time, the article offers a survey of the last period of the Lithuanian "Rytas" society of education (1939-1940): the growth of the number of its members and its reading-rooms, the establishment of new centres and other forms of activities. The article also provides a detailed account of distinct political bias of the Polish authorities towards the destruction of the "Rytas" activities which became evident in 1936 and continued until 1938: on January 29, 1938, the activities of the "Rytas" were suspended and on February 28, 1938, the society was closed down by voivod of Vilnius. On May 20, 1939, by common efforts of the "Rytas" society activists (the political situation for that purpose was favourable), the Vilnius voivod lifted the ban on this organization. Although burdened with big debts, the property owned by the "Rytas" was handed over back to it on June 6. The "Rytas" society which had been developing intensive activities since 1939 in spite of new impediments, like all other Catholic organizations, was closed down by the soviet authorities in 1940.
\end{abstract}

\section{Ivadas}

XX a. pradžioje Lietuvoje - Suvalkijoje, Aukštaitijoje ir Vilniaus krašte - pradejjusios veiklą „Žiburio“, „Saulès“ ir „Ryto“ draugijos atliko didžiulį darbą tautos švietimo, religinio ir tautinio sąmoninimo procese, tapo svarbiais lietuvių katalikiškąji intelektinị sąjūdị vienijančiais centrais.

Numalšinus 1863-1864 m. sukilimą itin sustiprintos carinės valdžios represijos turèjo neigiamų pasekmių lietuvių tautos kultūrai, mokslui, dvasingumui. Kaip lietuviškų mokyklų pakaitas atsiranda daraktoriai, uždraudus spaudą lotyniškais rašmenimis knygnešiai. Bažnyčios verčiamos cerkvėmis, vienuolynai uždarinėjami, bet tam aktyviai priešinamasi, tai liudija Kražiu įvykiai. Pasipriešinimo caro valdžios vykdomai politikai skatintojai - tautos švietẻjai, daugiausia dvasininkai. Ryškiausias jų - Žemaičių vyskupas Motiejus Valančius, kurio keltos idejos aktualios ir XXI a.

XIX a. pabaigoje ir XX a. pradžioje lietuviai katalikai intelektualai, siekę mokslų Rytuose (Peterburge ar Maskvoje) ir Vakaruose (Belgijoje, Šveicarijoje, Lenkijoje), pradejjo ten kurti ịvairias organizacijas bei draugijas, kurių tikslai buvo panašūs - lietuvybè, tikejjimas, mokslas, kultūra. 
Didelę reikšmę religiniam ir tautiniam sąmoninimui turejo kan. Juozo Tumo-Vaižganto (1869 $0908-18931128-19330429)^{1}$ redaguotas laikraštis "Tẻvynès sargas“ (1896-1904), kurị padèjo įsteigti Pranciškus Petras Būčys MIC (1972 0820 - 18990315 19300706 - 195110 25). Laikraštis sugriove katalikybès ir lenkybès tapatumo mitą, iš Bažnyčios buvo pašalintas lenkiškumas ir ji pamažu tapo tvirta lietuvybès atrama ${ }^{2}$.

Spaudos atgavimas sudare galimybes katalikams intelektualams pirmiausia reikštis šviečiamojoje srityje, vèliau - mokslinèje. Plati šviečiamoji veikla, kèlusi mokslo svarbą, jo būtinybę, buvo svarus pagrindas, formavęs, kreipęs ir skatinęs įvairias mokslo sritis.

Svetur veikusios draugijos buvo stimulas, atgavus lietuvišką spaudą, suaktyvinti veiklą

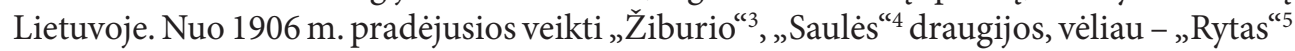
rūpinosi lietuvių švietimu, tautos kultūrinimu. Šioms draugijoms finansinę paramą teike Amerikos lietuviai, o draugijų nariai tapo žinomais katalikiškojo intelektinio sąjūdžio veikejjais, 1922 m. Kaune įsikūrusios Lietuvių katalikų mokslo akademijos nariais. Svarų pedsaką paliko Aleksandro Dambrausko-Jakšto redaguotas žurnalas „Draugija“6.

2013 m. sausio 31 d. paminètas Lietuvių švietimo draugijos „Rytas“ ”kūrimo 100-metis. Jubiliejus leido ištaisyti spaudoje įsigalejusias ir kai kurių tyrinètojų kartojamas klaidas, ypač dèl „Ryto“ draugijos veiklos sustabdymo ir uždarymo $1938 \mathrm{~m}$., nebeminint jos pastangų, atsispindinčių archyvinèje medžiagoje, suaktyvinti veiklą 1939 m. ir dirbti iki 1940 m., kai sovietų okupantai uždarẻ draugiją.

Darbo objektas - Lietuvių švietimo draugija „Rytas“.

Darbo tikslas - apžvelgti Vilniaus miesto ir Vilniaus krašto Lietuvių švietimo draugijos „Rytas“ 1939-1940 m. veiklos laikotarpi.

Uždaviniai: detalizuoti lenkų okupacinès valdžios naudotas priemones siekiant žlugdyti „Rytą", aptarti veiklos sustabdymą ir draugijos uždarymą (1938 m.); atskleisti centro valdybos pastangas atgaivinti „Ryto“ draugiją; pristatyti atkurtos „Ryto“ draugijos veiklos kryptis, išnagrinèti centro valdybos posėdžiu protokolus; apžvelgti „Ryto“ indèli puoselëjant lietuvybę Vilnijos krašte, propaguojant švietimą ir kultūrinị gyvenimą.

Metodai: duomenų rinkimas, literatūros analizè, jos susisteminimas, pateikimas, statistinis metodas.

„Ryto“ draugijai skirta negausi istoriografija, todèl pirmąsyk detalizuojama archyvinè nagrinėjamo laikotarpio medžiaga. Apie „Ryto“ draugiją informacijos yra pateikęs kun. Petras Kraujalis (1882 0708 - 1907 - 193308 14), pasirašęs slapyvardžiu, duomenų yra ir P. Kraujaliui skirtame straipsnių rinkinyje ${ }^{8}$, „Ryto“ draugija detaliai apžvelgta prof. Jūratės Kiaupienès paskelbtuose tyrinëjimuose (nors čia atiduota privaloma duoklè mokslinių publikacijų reikalavimams sovietmečiu $)^{9}$ ir straipsniuose, nagrinëjančiuose „Ryto“ draugijos istoriją ${ }^{10} .2012$ m. pasirode knyga, skirta „Ryto" draugijos šimtmečiui ${ }^{11}$, bet tenka apgailestauti, kad joje gana daug netikslumų ir ypač gausu korektūros klaidų.

„Ryto“ draugijos istorijai itin svarbi medžiaga saugoma Lietuvos mokslų akademijos Vrublevskių bibliotekos Rankraščiu skyriuje, „Ryto“ draugijos fonde ${ }^{12}$.

Paskutini „Ryto “ draugijos veiklos laikotarpi (1939-1940) atspindi „Ryto “ draugijos centro valdybos protokolai, saugomi minètame „Ryto“ draugijos fonde (signatūra F $67-264 / 5)^{13}$.

Remiantis šia ir kitų „Ryto“ draugijos fondo bylų medžiaga, detalizuojama „Ryto“ veikla $1939-1940 \mathrm{~m}$. 
Tačiau prieš kalbant apie minimą laikotarpị, būtina apžvelgti draugijos padètị paskutiniais metais, kai jos veiklą lenkų valdžia sustabdè, o vẻliau ir uždraudè.

\section{Nuo „Ryto“ draugijos veiklos varžymo iki jos uždraudimo}

Dar prieš Vilniaus miesto storastijai (tai atitiktų šiuolaikinės seniūnijos, savivaldybès statusą) $1938 \mathrm{~m}$. sausio 29 d. sustabdant „Ryto“ draugijos veiklą, o po ménesio, $1938 \mathrm{~m}$. vasario 28 d., Vilniaus vaivadijai ją uždarant, jautèsi akivaizdus šio lietuviško židinio naikinimas - „Ryto“ veikla nuo pat pradžių buvo prieštaravimo, o vẻliau ir neapykantos objektas. Apie tai kalbėta draugijos valdybos posėdžiuose 1938-1940 m. (ir ankstesniuose). Posėdžių periodiškumą liudija 1 lentelè.

1 lentelè. Lietuvių švietimo draugijos „Rytas“ centro valdybos posėdžiai 1938-1940 m. (sudaryta remiantis LMAVB RS F 67 - 264/5 medžiaga)

\begin{tabular}{|c|c|c|c|c|c|}
\hline $\begin{array}{l}\text { Eil. } \\
\text { nr. }\end{array}$ & $\begin{array}{l}\text { Posèdžių } \\
\text { data }\end{array}$ & Posėdyje dalyvavo & $\begin{array}{l}\text { Pro- } \\
\text { tokolo } \\
\text { numeris }\end{array}$ & Lapai byloje & $\begin{array}{l}\text { Posèdžių } \\
\text { vieta }\end{array}$ \\
\hline 1. & 19380113 & $\begin{array}{l}\text { Krištapas Čibiras (pirm.), Marcelinas } \\
\text { Šikšnys (vicepirm.), Vincas Budrevičius } \\
\text { (sekretor.). Nariai: Aleksandras } \\
\text { Petraitis, Konstantinas Stašys, Antanas } \\
\text { Juknevičius, Rapolas Mackevičius }\end{array}$ & 264 & L. 11 & $\begin{array}{l}\text { Vytauto } \\
\text { Didžiojo } \\
\text { gimnazija } \\
\text { (VDG) - } \\
\text { butas (b) }\end{array}$ \\
\hline 2. & 19390606 & $\begin{array}{l}\text { K. Čibiras (pirm.), M. Šikšnys } \\
\text { (vicepirm.), V. Budrevičius (sekretor.). } \\
\text { Nariai: A. Petraitis, K. Stašys, } \\
\text { A. Juknevičius, R. Mackevičius }\end{array}$ & 265 & $\begin{array}{l}\text { L. } 11 \text { a.p. } \\
\text { - } \\
\text { L. } 12 \text { a.p. }\end{array}$ & VDG - b \\
\hline 3. & 19390624 & $\begin{array}{l}\text { K. Čibiras (pirm.), V. Budrevičius } \\
\text { (sekretor.). Nariai: A. Petraitis, K. Stašys, } \\
\text { A. Juknevičius, R. Mackevičius }\end{array}$ & 266 & L. 13 - L. 15 a. p & VDG - b \\
\hline 4. & 19390627 & $\begin{array}{l}\text { K. Čibiras (pirm.), M. Šikšnys } \\
\text { (vicepirm.), V. Budrevičius (iždininkas), } \\
\text { K. Pukènas (sekretor.). Nariai: K. Stašys, } \\
\text { A. Juknevičius, R. Mackevičius }\end{array}$ & 267 & $\begin{array}{l}\text { L. } 15 \text { a.p. } \\
- \\
\text { L. } 17 \text { a.p. }\end{array}$ & VDG - b \\
\hline 5. & 19390708 & $\begin{array}{l}\text { K. Čibiras (pirm.), V. Budrevičius } \\
\text { (iždininkas), K. Pukènas (sekretor.). } \\
\text { Nariai: A. Juknevičius, R. Mackevičius }\end{array}$ & 268 & L. 17 a. p. - L. 22 & $\begin{array}{l}\text { "Ryto" } \\
\text { bute }\end{array}$ \\
\hline 6. & 19390713 & $\begin{array}{l}\text { K. Čibiras (pirm.), M. Šikšnys } \\
\text { (vicepirm.), V. Budrevičius (iždininkas), } \\
\text { K. Pukėnas (sekretor.). Nariai: K. Stašys, } \\
\text { A. Juknevičius, R. Mackevičius }\end{array}$ & 269 & L. 22 a.p. & $\begin{array}{l}\text { „Ryto“ } \\
\text { bute }\end{array}$ \\
\hline 7. & 19390716 & $\begin{array}{l}\text { K. Čibiras (pirm.), M. Šikšnys } \\
\text { (vicepirm.), V. Budrevičius (iždininkas), } \\
\text { K. Pukènas (sekretor.). Nariai: K. Stašys, } \\
\text { A. Juknevičius, R. Mackevičius }\end{array}$ & 270 & L. 23 - L. 25 & $\begin{array}{l}\text { "Ryto" } \\
\text { bute }\end{array}$ \\
\hline
\end{tabular}




\begin{tabular}{|c|c|c|c|c|c|}
\hline 8. & 19390719 & $\begin{array}{l}\text { K. Čibiras (pirm.), M. Šikšnys } \\
\text { (vicepirm.), V. Budrevičius (iždininkas), } \\
\text { K. Pukėnas (sekretor.). Nariai: K. Stašys, } \\
\text { A. Juknevičius, R. Mackevičius }\end{array}$ & 271 & L. 25 a. p. - L. 26 & $\begin{array}{l}\text { "Ryto" } \\
\text { bute }\end{array}$ \\
\hline 9. & 19390720 & $\begin{array}{l}\text { K. Čibiras (pirm.), M. Šikšnys } \\
\text { (vicepirm.), V. Budrevičius (iždininkas), } \\
\text { K. Pukėnas (sekretor.). Nariai: K. Stašys, } \\
\text { A. Juknevičius, R. Mackevičius }\end{array}$ & 272 & L. 26 - L. 28 & $\begin{array}{l}\text { "Ryto" } \\
\text { bute }\end{array}$ \\
\hline 10. & 19390724 & $\begin{array}{l}\text { K. Čibiras (pirm.), M. Šikšnys } \\
\text { (vicepirm.), V. Budrevičius (iždininkas), } \\
\text { K. Pukėnas (sekretor.). Nariai: K. Stašys, } \\
\text { A. Juknevičius, R. Mackevičius }\end{array}$ & 273 & L. 28 - L. 30 & $\begin{array}{l}\text { "Ryto" } \\
\text { bute }\end{array}$ \\
\hline 11. & 19390728 & $\begin{array}{l}\text { K. Čibiras (pirm.), M. Šikšnys } \\
\text { (vicepirm.), V. Budrevičius (iždininkas), } \\
\text { K. Pukėnas (sekretor.). Nariai: K. Stašys, } \\
\text { A. Juknevičius, R. Mackevičius }\end{array}$ & 274 & L. 30 - L. 33 & $\begin{array}{l}\text { "Ryto" } \\
\text { bute }\end{array}$ \\
\hline 12. & 19390804 & $\begin{array}{l}\text { K. Čibiras (pirm.), M. Šikšnys } \\
\text { (vicepirm.), V. Budrevičius (iždininkas), } \\
\text { K. Pukėnas (sekretor.). Nariai: K. Stašys, } \\
\text { A. Juknevičius, R. Mackevičius }\end{array}$ & 275 & L. 33 - L. 34 a.p. & $\begin{array}{l}\text { „Ryto“ } \\
\text { bute }\end{array}$ \\
\hline 13. & 19390810 & $\begin{array}{l}\text { K. Čibiras (pirm.), M. Šikšnys (vice- } \\
\text { pirm.), V. Budrevičius (iždininkas), } \\
\text { K. Pukėnas (sekretor.). Nariai: K. Stašys, } \\
\text { A. Juknevičius, R. Mackevičius }\end{array}$ & 276 & L. 35 - L. 37 a. p. & $\begin{array}{l}\text { „Ryto“" } \\
\text { bute }\end{array}$ \\
\hline 14. & 19390816 & $\begin{array}{l}\text { K. Čibiras (pirm.), M. Šikšnys } \\
\text { (vicepirm.), V. Budrevičius (iždininkas), } \\
\text { K. Pukėnas (sekretor.). Narys: K. Stašys, } \\
\text { A. Juknevičius }\end{array}$ & 277 & L. 38 - L. 45 & $\begin{array}{l}\text { "Ryto" } \\
\text { bute }\end{array}$ \\
\hline 15. & 19391215 & $\begin{array}{l}\text { M. Šikšnys (vicepirm.), V. Budrevičius } \\
\text { (iždininkas), K. Pukènas (sekretor.). } \\
\text { Narys: K. Stašys }\end{array}$ & 278 & L. 45 - L. 46 a.p. & VDG \\
\hline 16. & 19400110 & $\begin{array}{l}\text { K. Čibiras (pirm.), V. Budrevičius } \\
\text { (iždininkas), K. Pukènas (sekretor.). } \\
\text { Nariai: K. Stašys, R. Mackevičius }\end{array}$ & 279 & L. 46 a. p. - L. 47 & VDG \\
\hline 17. & 19400312 & $\begin{array}{l}\text { K. Čibiras (pirm.), A. Juknevičius (pirm. } \\
\text { pavad.), V. Budrevičius (kasininkas), } \\
\text { Karolis Gumbaragis (knygininkas), } \\
\text { Jonas Naujalis (sekretor.). Nariai: } \\
\text { Nikodemas Vaišutis, K. Stašys }\end{array}$ & 280 & L. 48 & $\begin{array}{l}\text { Nenuro- } \\
\text { dyta }\end{array}$ \\
\hline 18. & 19400706 & $\begin{array}{l}\text { K. Čibiras (pirm.), V. Budrevičius (kasi- } \\
\text { ninkas), J. Naujalis (sekretor.). Narys: } \\
\text { N. Vaišutis }\end{array}$ & 281 & L. 48 - L. 49 a.p. & $\begin{array}{l}\text { Nenuro- } \\
\text { dyta }\end{array}$ \\
\hline
\end{tabular}

Lentelëje pateikiami duomenys apie „Ryto“ draugijos valdybos sudètį, narių užimamas pareigas. Nagrinejjamu laikotarpiu „Ryto“ pirmininko pareigas èjo kun. Krištapas (taip rašyta daugelyje dokumentų) Čibiras (1888 1214 - 19140531 - 194203 23). Tai šeštas ir paskutinis „Ryto“ draugijos pirmininkas ${ }^{14}$, jai vadovavęs beveik septynerius metus (19330814-193802 28 ir 19390520 - 194007 08), kol sovietiné valdžia uždraudè „Ryto“, kaip ir kitų katalikiškų organizacijų, veiklą. 


\section{1. „Ryto“ ịkurtų skyrių, skaityklų, mokyklų naikinimas}

1938 m. sausio 12-13 d. Vilniaus miesto storastijos valdininkai Vulcas ir Kviatkovskis atliko „Ryto“ draugijos reviziją ${ }^{15}$. Po poros savaičių, $1938 \mathrm{~m}$. sausio 29 d., Vilniaus miesto storastijos raštu L. dz. B-32/38 d. „Ryto“ draugijos veikla buvo sustabdyta. Jos reikalams vesti paskirtas kuratorius advokatas Steponas Vilanovskis (Stepan Wilanowski). „Ryto“ valdyba, nesutikdama su priekaištais draugijai ir laikydama juos nepagrịstais bei neatitinkančiais tikrovès, $1938 \mathrm{~m}$. vasario $9 \mathrm{~d}$. raštu apskundè Vilniaus miesto storastijos sprendimą Vilniaus vaivadai Liudvikui Bocianskiui. Po dviejų savaičių, 1938 m. vasario 25 d., Vilniaus vaivada decizija (įsakymu, nutartimi) Nr. SPP. 19, remdamasis storastijos raštu, storastijos sprendimą patvirtino ir po trijų dienų - $1938 \mathrm{~m}$. vasario $28 \mathrm{~d}$. - minètu raštu Nr. SPP. 19 „Ryto“ draugijos veiklą nutrauke $\dot{e}^{16}$.

Nors „Ryto“ valdyba dèl tokio L. Bocianskio sprendimo (skunde plačiai nagrinèti draugijai pateikti priekaištai, pavyzdžiui, dèl „Ryto“veiklos, pavojingos valstybei, ir pan.) 1938 m. kovo 14 d. raštu kreipèsi ị Vidaus reikalų ministeriją, bet ị ši raštą-skundą atsakymo nesulaukè iki 1939 m. birželio $6 \mathrm{~d}$.

„Ryto“ draugija ir Lietuvių mokslo draugija. Komplikuojantis padéčiai „Ryto“ draugija ne tik siekè įvairiais būdais plètoti veiklą, bet ir išsaugoti turimas vertybes. Negavus valdžios leidimo atidaryti skolinamąji knygyną, centro valdyba $1938 \mathrm{~m}$. sausio $13 \mathrm{~d}$. posėdyje nusprendè visas turimas knygas, archeologinius rinkinius ir archyvinę medžiagą padovanoti Lietuvių mokslo draugijai (toliau - LMD). Be to, nutarẻ padovanoti ir turimą inventorių, išskyrus vieną rašomąjį stalą ir 4 kèdes ${ }^{17}$.

„Ryto“ draugijos materialiniai ryšiai su LMD formavosi jau anksčiau. Dar $1937 \mathrm{~m}$. LMD prašè jiems perleisti su visais daiktais kambarị, kuriame buvo „Ryto“ knygynas ir muziejiniai eksponatai, ateityje tikèdamiesi, kad, jų prašymu, bus perleista raštinè, pirmininko kabinetas ir kiti kambariai. Ši LMD prašymą „Ryto“ draugijos valdyba svarstė $1937 \mathrm{~m}$. birželio $9 \mathrm{~d}$. ir nutare ji patenkinti ${ }^{18}$. Valdyba taip pat nutarẻ ateityje LMD atiduoti visą antrųjų rūmų patalpą su sąlyga, jog jie už tuos rūmus mokès visus mokesčius ir atliks kitas pareigas, o „Rytui“ per metus mokès po 20 auksinų nuomos. Tačiau toks „Ryto“ pasiūlymas LMD netenkino, todèl abipusiu lapkričio $24 \mathrm{~d}$. susitarimu valdybos narių pasirašytas dokumentas-sutartis, kad „Ryto“ draugija mokès valstybinius mokesčius ir atliks išorinị namų remontą, o LMD mokès didesnę - 2000 auksinų - nuomą ${ }^{19}$.

\section{2. „Ryto“ draugijos uždarymas $1938 \mathrm{~m}$. vasario $28 \mathrm{~d}$. ir pastangos ją atkurti}

Apie "Ryto“ draugijos veiklos sustabdymą detaliai kalbejo draugijos pirmininkas kun. K. Čibiras 1939 m. birželio 6 d. posèdyje. Šiame straipsnyje perteikiama draugijos istorijai itin svarbi, nepublikuota medžiaga:

1938 m. sausio 29 d. Vilniaus miesto storastos raštu L. dz. B-32/38 sulaiké „Ryto“ draugijos veikimą ir paskyrė jos reikalams vesti kuratorių advokatą Steponą Wilanowski. Valdyba, nesutikdama su daromais draugijai priekaištais ir laikydama juos nepagrịstais ir neatitinkančiais tikrovès, ịskundè Vilniaus miesto Storastos sprendimą Vilniaus vaivadai p. L. Bocianskiui raštu, rašytu $1938 \mathrm{~m}$. vasario $9 \mathrm{~d}$. 
Vilniaus vaivada decizija iš $1938 \mathrm{~m}$. vasario 25 d. Nr. SPP. 19 p. Storastos sprendimą užtvirtino dẻl motyvų, išdèstytų Storastos rašte.

1938 m. vasario 28 d. raštu Nr. SSP. 19 Vilniaus vaivada draugiją uždarè. Valdyba ịskundè p. vaivados Bocianskio sprendimą Vidaus reikalų ministerijai raštu 1938 m. kovo 14 d. ir ị tą raštą nesulaukè atsakymo iki 1939 m. birželio 6 d. Skunde buvo plačiau nagrinèti draugijai daromi priekaištai.

Kadangi tuo pačiu laiku buvo uždarytos ir kitos lietuvių draugijos, viso 9, tai jų visų reikalu lietuvių visuomené kelis kartus kreipèsi ị centrines ịstaigas jau per delegacijas, jau raštais.

1939 m. gegužès 20 d. Vilniaus vaivadija ị „Ryto“ draugijos gegužès 17 d. prašymą raštu Nr. SPP. 651 atšaukè savo deciziją iš 1938 m. vasario 28 d. Nr. SPP. 19 ir itsakè p. S. Wilanowskio îpédiniui kuratoriui [padalinio, besirūpinančio švietimo veikla (pagal šių dienų supratimą - švietimo skyriaus), vadovui - A. V. past.] Juozapui Prokopczukui draugijos turtą perduoti senajai valdybai. Perdavimo aktas ịvyko $1939 \mathrm{~m}$. birželio $6 \mathrm{~d}$. Draugijos aktyvai ir pasyvai sužymèti perdavimo - prièmimo protokole, kurị pasirašè kuratorius p. J. Prokopczuk, Vilniaus miesto storastijos atstovas p. Jan Kwiatkowski ir valdybos nariai. Draugijos namai Vilniuje, Antakalnio gatvè Nr. 6/1 perejo draugijai iš kuratelès apsunkinti hipotekine skola bankui Gospodarstwa Krajowego sumoje 60.000 zlotų. Be to, draugijai teko priimti įvairių neapmokètų sąskaitų sumoje $7745 \mathrm{zl} 89$ sk neskaitant priklausomų už pavèlavimą nuošimčių. Draugijai priklausomos sumos iš skolininkų ir nuomininkų perėmimo dieną sudaré 33303 zlotų. Valdyba, perimdama draugijos turtą, kvestionavo Banko Gospodarstwa Krajowego skolos teisètumą. Buvo pasiūlymas įrašyti perèmimo protokolan pastabą dèl anos skolos teisètumo, bet kuratorius p. J. Prokopczukas su tuo nesutiko ir atsisake draugijos turtą perduoti, tad protokolas pasirašytas be pastabos, su įsitikinimu, kad tuo pasirašymu paskolos charakteris nekeičiamas ir jos galimi juridiniai trūkumai paliekami spręsti teismui. Tos nuomonès laikès ir Vilniaus miesto storastijos atstovas. Dèl tos skolos jau anksčiau buvo užvesta teismo byla.

Vaivadijoje pranešant draugijos atstovams kun. Krištapui Čibirui, p. Konstantinui Stašiui ir p. Marcelinui Šikšniui apie jos uždarymo nuẻmimą ir įteikiant $1939 \mathrm{~m}$. gegužès 20 d. atidarymo raštą, buvo pareikšta, kad draugija galès steigti skyrius, skaityklas ir mokyklas lietuvių gyvenamose vietose, kur lietuvių yra dauguma. Tai atrodo draugijos veikimo teisių susiaurinimu. Be to, tai buvo pasakyta žodžiu, atidavimo rašte jokių siaurinimų nèra. ${ }^{20}$

\section{2. „Ryto“ draugijos atkūrimas ir veiklos kryptys}

Prieš tai pateiktame dokumente rašoma, kad 1939 m. gegužès 20 d. „Ryto“ draugijos veiklos uždraudimas panaikinamas, o birželio $6 \mathrm{~d}$. perduotas (sugrąžintas), bet jau su didelèmis skolomis, draugijai priklausęs turtas.

Minètame $1939 \mathrm{~m}$. birželio $6 \mathrm{~d}$. posedyje kalbèta apie skubų atkuriamajj draugijos darbą. Jau birželio 25 d. Šv. Mikalojaus parapijos salejje nuspręsta sušaukti visuotinị 
„Ryto“ draugijos susirinkimą. Be to, nutarta raštu kreiptis i Balstogès vaivadiją su prašymu atšaukti 1936 m. gruodžio 26 d. raštą, kuriuo buvo uždrausta „Ryto“ veikla pasienyje. Nuspręsta priimti naujus narius ir steigti kaimuose „Ryto“ draugijos skyrius.

Posėdyje svarstytas patalpų klausimas. Kadangi anksčiau turètas butas išnuomotas LMD ir negalèjo būti toliau naudojamas, nutarta draugijos raštinei ir bibliotekai panaudoti butą Nr. 1 pirmuosiuose draugijos namuose Antakalnio g. 6/1.

Taigi „Ryto“ draugija pradejo intensyvią veiklą burdama lietuvius. Siekdama sudaryti sąlygas lietuvybès plètrai, èmėsi įvairiausių žygių.

\subsection{Lietuviškụ mokyklụ steigimo problemos}

Dèl tolesnès lietuvių švietimo veiklos jau birželio 10 d. kun. K. Čibiras ir M. Šikšnys apsilankė Mokyklų kuratorijoje pas Godeckị. Išaiškejjo, kad mokyklas galima steigti ten, kur nèra valdžios mokyklų ir kurios nuo artimiausios mokyklos toliau nei trys kilometrai. Valdžios mokyklose buvo privalu palikti dèstomąją valstybinę kalbą, lietuvių kalba galèjo būti tik kaip neprivalomas dalykas. Tačiau, pasak Godeckio, būtina kelti mokymo lygi. Naujos lietuviškos mokyklos negalèjo būti steigiamos, nes kuratorijai trūko kreditų. "Ryto“ mokyklose dirbę lietuviai mokytojai ị darbą negalèjo būti grąžinami, kadangi jie valdžios mokyklose dirbtų tik materialiniais sumetimais. Seniau dirbę mokytojai ir dabar dirbą nelietuviškose vietovėse nenori grị̌ti ị senąsias vietas, nes jose darbas yra sunkesnis: ne tik mažas skyrių skaičius mokyklose, bet ir lietuvių visuomenès keliami dideli reikalavimai. Aptardami tautystės deklaraciją kun. K. Čibiras ir M. Šikšnys siūlè jas, kaip lietuvius žeminančias ir įžeidžiančias, visai panaikinti. Kuratorius ị tą pageidavimą nieko neatsakè $\dot{2}^{21}$.

Po visuotinio susirinkimo išrinktoji „Ryto“ valdyba $1939 \mathrm{~m}$. birželio 27 d. posėdyje pasidalijo pareigas (žr. 1 lentelę).

„Ryto“ pirmininkas kun. K. Čibiras lankèsi kuratorijoje pas Liaudies mokyklų skyriaus viršininką Gryglewskị dèl 7 skyrių liaudies mokyklos steigimo Švenčionyse, tačiau šis labai nepalankiai reagavo ị toki pageidavimą.

Valdyboje pasidžiaugta, kad Šv. Kazimiero draugija „Rytui“ padovanojo per $600 \mathrm{~kg}$ knygų, bet dali naujų knygų storastijos cenzorius sulaike ir 98 kg buvo grąžinti atgal i Kauną.

\subsection{Sunkumai kuriant „Ryto“ draugijos skyrius}

Aptarta skyrių steigimo procedūra, kalbèta apie skolas. „Ryto“ draugijai daugiausia buvo i̊siskolinusi Lietuvių mokslo mylètojų draugija ${ }^{22}$ (7350 auksinų). Pirmininkas su jais jau taręsis ir nuspręsta laikytis ankstesnès, 1937 m. nuomos sutarties. Numatyti „Ryto“ draugijos pastatų remonto darbai (įtaisyti bendrą anteną, nudažyti tvorą, atlikti išorinị namų remontą, pastatus prijungti prie miesto kanalizacijos).

Ikurtų skyrių veiklos sunkumus detalizavo kun. K. Čibiras ${ }^{23}$. (Duomenys apie „Ryto“ draugijos skyrių kūrimą $1939 \mathrm{~m}$. vasarą pateikti 2 lentelèje.) Tai ir vietinès storastijos atsisakymas patvirtinti įsteigtus skyrius dèl nesumokètų žyminių mokesčių, dèl ị valdybas 
išrinktų Šv. Kazimiero draugijos narių. Tokį neigiamą požiūrị itin stiprino lenkų mokytojų antiagitacinè veikla, padètis pasienio ruože. Galima pateikti keletą pavyzdžių. Pasak pirmininko, Švenčionèliu gyventojai kreipèsi ị storastą, prašydami patvirtinti naujai ịkurtą „Ryto“ skyrių. Storasta pareikalavo žyminio mokesčio, nuo kurio atleistos visos švietimo draugijos. Tada „Ryto“ draugijos centro valdyba kreipessi i Vilniaus iždinę, prašydama pažymèjimo, kad „Rytas“, kaip ir kitos švietimo draugijos, atleistas nuo mokesčio. Švenčionių storastai pranešta, jog, remiantis įstatais, „Rytas“ neprivalo mokèti žyminio mokesčio.

Daug problemų kèlè ir Švenčionių mokytojai lenkai - dare ịtaką gyventojams ir mokinių tèvams. Tad neatsitiktinai dalis steigiamo Miežionèlių skyriaus narių panoro išstoti iš „Ryto“ draugijos. Tik apsilankius valdybos nariui kun. Kazimierui Pukenui (1905 0229 19320619 - 19970419$)$ ir viską išaiškinus, prašèsi priimami atgal ir pageidavo ịkurti skyrių.

Negavus jokio atsakymo iš Balstogès vaivadijos, kurioje prieš porą metų buvo uždrausta bet kokia „Ryto“ veikla pasienio ruože, nuspręsta vietoje išsiaiškinti, kodèl neatsakyta ị raštišką „Ryto “ kreipimąsi. Atvykęs kun. K. Pukėnas sužinojo, kad vaivadija negalinti panaikinti savo jau ịsigalèjusio sprendimo, o atsakymo ị ministerijai nusiųstą bylą dar nesulaukta. Kun. K. Pukẻnui paklausus, ką daryti su gaunamais prašymais skyrių ir skaityklų klausimu ir ar draudimas galioja ir šiuo metu, saugumo viršininkas atsakęs, jog skyrius ir skaityklas galima steigti, o vaivadija tuos prašymus spręsianti individualiai ${ }^{24}$. „Rytas“ netruko pasinaudoti tokiu pareiškimu.

Kun. K. Pukènas važiavo išsiaiškinti, ar Švenčionių storastija nepatvirtino Švenčionèlių, Miežionèlių ir Guntauninkų skyrių dèl teisinių priežasčių, ar ịtakos turëjo neigiamas nusistatymas „Ryto“ atžvilgiu. Vicestorasta Pulnowskis pareiškè, kad nepatogu tvirtinti skyrius, kurių valdyboje buvę Šv. Kazimiero draugijos valdybos nariai. Pasiteiravus, ar bus tvirtinama, jei bus pakeisti valdybos nariai, sulaukta teigiamo atsakymo, nors ir su tam tikra išlyga.

Sužinota, kad Lydos storastija nepatvirtino Dubičių skyriaus, nors kreipèsi pats skyrius. Kai kuriose vietovèse policija trukdè sušaukti „Ryto“ skyriaus steigiamajji susirinkimą. Adutiškio valsčiaus Svylionių k. gyventojai net du kartus buvo išvaikyti. Reikejo iš Vilniaus važiuoti centro valdybos sekretoriui, įrodyti steigiamojo susirinkimo sušaukimo teisètumą.

Kadangi pateikus prašymą registruoti skyrių atsakymas iš storastijos negautas 4 savaites, galejo veikti Pošalčių, Rudnios ir Papiškių „Ryto“ skyriai.

Sudètinga padètis buvo ir atkuriant „Ryto“ skaityklas, dažniausiai nurodoma priežastis - patalpų netinkamumas. Vilniaus-Trakų storastija pažadèjo leisti veikti uždarytai skaityklai Kaniaukoje. Tuo norèta remtis ir aiškinantis, kodèl delsiama atidaryti skaityklą Breslaujoje.

Tačiau Breslaujos storastijos saugumo referentas nežinojo, kaip ši klausimą išspręsti. Kreipiantis ị aukštesniają valdžią išaiškinta, kad skaityklos neegzistuoja, yra tik jų inventorius, kuris bus perduotas naujai atidarytoms skaitykloms. „Ryto“ draugijos centro valdybos sekretorius kun. K. Pukẻnas išgirdo pagrịstus priekaištus dèl buvusių skaityklų patalpų: jas reikia suremontuoti, o geriausia išsinuomoti naujas. Pažadèta „Ryto“ draugijos skaityklas laikyti lygiomis su kitomis. 
1939 m. rugpjūčio 16 d. centro valdybos posèdyje svarstyti ir priimti svarbūs sprendimai $^{25}$. Vienas jų - skyrių veikla. Nutarta visame Vilniaus krašte steigti skyrius, siekiant geresnès jų veiklos organizuoti parapinius arba valsčių-rajonų (kur galima - ir apskričių) skyrius. Rajonų priešakyje - veiklos komitetas (trys nariai, renkami skyrių valdybų pirmininkų ir sekretorių), susirenkantis kas trys mènesiai. Centras gi turi organizuoti specialistus paskaitoms, aprūpinti reikiama medžiaga susirinkimuose.

Skyrių veiklos kryptys ir formos. 1939 m. rugpjūčio $16 \mathrm{~d}$. centro valdybos posèdyje patvirtintos „Ryto“ veiklos formos: susirinkimai, rajoniniai suvažiavimai, jaunimo sąskrydžiai, savaičių ir iškilmingos dienos (kultūrinès propagandos, kovos su ydomis savaitės). Planus ir repertuarą turejjo parengti centras. Svarbi veiklos forma - rajonuose ir centruose organizuojami kursai skyrių vadovams ir skaityklų vedẻjams.

Tame pačiame posėdyje nutarta, kad skyriai organizuotų skaityklas ir knygynèlius, registruotų narius (sąrašą privalo turèti ir centro valdyba). Skaityklos organizuojamos keliems kaimams trijų kilometrų spinduliu. Prie skaityklos turètų būti knygynèliai, kurie aprūpintų gretimų kaimų gyventojus. Jei pirmiau ịsikuria skaitykla, tai skaityklų vedèjai organizuoja „Ryto“ draugijos skyrius, padeda jiems veikti, aprūpina knygomis. Tam ypač svarbūs kilnojamieji knygynèliai: rudenị jie išsiunčiami, o vasaros pradžioje - surenkami ir sukeičiami. Už visas knygas atsako vedejjas.

1939 m. rugpjūčio 16 d. valdybos posèdyje spręstas „Ryto“ darbuotojų atlyginimų klausimas. Nutarta baigusiems universitetą pirmus tris mėnesius mokèti po 150 zlotų, paskui - po 180 .

Posėdyje kalbèta ir apie „Ryto“ draugijos 25 metų veiklos jubiliejų, kuris turèjo būti paminètas $1938 \mathrm{~m}$., tačiau to padaryti nebuvo galima, nes draugija uždaryta ir ją valdè valdžios paskirtas kuratorius. Nuspręsta minèti gruodžio mėnesį: organizuoti kursus, juos baigiant - akademiją, vaidinimą ir draugišką arbatèlę.

\section{3. „Ryto“ draugijos nariụ skaičiaus augimas ir skyriụ kūrimas}

Per 1939 m. birželio 24 d. - rugpjūčio 16 d. draugijos valdybos sušauktus 12-a posèdžių daugiausia svarstyti i „Ryto“ draugiją stojančiųjų pareiškimai, naujų narių prièmimo klausimas (žr. 2 lentelę). Iš lentelès duomenų matyti, kad 1939 m. birželio-rugpjūčio mėnesiais ị „Ryto“ draugiją ísijungė 103 skyriai Vilnijos krašto kaimuose, sodžiuose bei miestuose, pačiame Vilniuje vèl pradejjo veikti „Ryto“ skyriai, įsitraukè apie 1500 naujų narių.

Matyti, kad birželio 24 d. posèdyje ị „Ryto“ draugiją priimta 119 asmenų iš 7 kaimų ir Vilniaus bei Švenčionèlių miestų ${ }^{26}$, birželio 27 d. iš dviejų sodžių (Kapiniškių ir Miežionèlių) priimta 50 asmenų ${ }^{27}$. Liepos mėnesi „Ryto“ valdyba posėdžiauti rinkosi net septynis kartus: liepos $8 \mathrm{~d}$. (ị draugiją îstojo 250 asmenų iš 14 kaimų) $)^{28}$, liepos $13 \mathrm{~d}$. (17-a Dubičių kaimo gyventojų $)^{29}$, liepos 16 d. (140 asmenų iš 12 kaimų) $)^{30}$, liepos 19 d. (14 gyventojų iš Mielagėnų ir 24 - iš Krūminių kaimų) $)^{31}$, liepos 20 d. (105 asmenys iš 10 kaimų $)^{32}$, liepos 24 d. - 95 iš penkių kaimų (Drucminų - 20, Piliakalnio - 13, Svylionių - 33, Mištūnų - 16, Strèžiūnų - 13) ${ }^{33}$, liepos 28 d. $(168 \text { - iš } 14 \text { kaimų })^{34}$. Rugpjūčio mènesị trijuose posédžiuose taip pat buvo svarstytas naujų narių prièmimas ị „Ryto“ draugiją: 
rugpjūčio $4 \mathrm{~d}$. (93 - iš 8 kaimų $)^{35}$, rugpjūčio $10 \mathrm{~d}$. (13 - iš Dieveniškių miestelio ir 152 iš 10 kaimų $)^{36}$ ir rugpjūčio $16 \mathrm{~d}$. (10 - iš Marcinkonių miestelio, 12 - iš Švenčionèlių ir 284 asmenys iš 30 kaimų; būtina pažymèti, kad pastarojo posėdžio metu kai kurie priimti nariai papildè jau veikusius skyrius, tačiau protokolų sąrašuose yra ir pasikartojančių

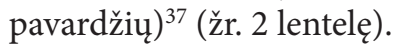

2 lentelè. „Ryto“ draugijos skyrių kürimas kaimuose 1939 m. vasarą

(sudaryta remiantis LMAVB RS F 67 - 264/5 medžiaga)

\begin{tabular}{|c|c|c|c|c|c|}
\hline $\begin{array}{l}\text { Eil. } \\
\text { nr. }\end{array}$ & $\begin{array}{l}\text { "Ryto“ } \\
\text { draugijos } \\
\text { valdybos } \\
\text { posèdžio data }\end{array}$ & $\begin{array}{l}\text { Protokolo } \\
\text { numeris }\end{array}$ & $\begin{array}{l}\text { Ikurtų } \\
\text { „Ryto“ } \\
\text { draugijos } \\
\text { skyrių } \\
\text { skaičius }\end{array}$ & Vietovių pavadinimai & $\begin{array}{c}\text { İstojusiu } \\
\text { ì „Ryto“ } \\
\text { draugiją } \\
\text { narių } \\
\text { skaičius }\end{array}$ \\
\hline 1. & 19390624 & 266 & 9 & Vilniaus miestas & 10 \\
\hline 2. & & & & Guntauninkų k. & 10 \\
\hline 3. & & & & Pošalčių k. & 24 \\
\hline 4. & & & & Pirčiupių k. & 11 \\
\hline 5. & & & & Papiškių k. & 10 \\
\hline 6. & & & & Senųjų Naniškių k. & 14 \\
\hline 7. & & & & Urkionių k. & 11 \\
\hline 8. & & & & Rudnios k. (Vilniaus-Trakų apskr.) & 6 \\
\hline 9. & & & & Švenčionèlių miestas & 23 \\
\hline \multirow[t]{2}{*}{10.} & 19390627 & 267 & 3 & Kapiniškių sodžius & 18 \\
\hline & & & & Pošalčių sodžius & $24^{*}$ \\
\hline 11. & & & & Miežionèlių sodžius & 32 \\
\hline 12. & 19390708 & 268 & 14 & Geniūnų k. & 10 \\
\hline 13. & & & & Gaurelių k. & 11 \\
\hline 14. & & & & Daržininkų k. & 41 \\
\hline 15. & & & & Krokšlio k. & 10 \\
\hline 16. & & & & Kuršių k. & 46 \\
\hline 17. & & & & Randamonių k. & 15 \\
\hline 18. & & & & Margonių k. & 12 \\
\hline 19. & & & & Veikūnų ir Vẻjinės I, II k. & 12 \\
\hline 20. & & & & Vidugirių k. & 10 \\
\hline 21. & & & & Vigonių k. & 14 \\
\hline 22. & & & & Voriškių k. & 14 \\
\hline 23. & & & & Senụjų Ramonų k. & 11 \\
\hline 24. & & & & Grybų k. & 11 \\
\hline 25. & & & & Juodiškių k. & 13 \\
\hline 26. & 19390713 & 269 & 1 & Dubičių k. & 17 \\
\hline 27. & 19390716 & 270 & 12 & Žagarių k. & 10 \\
\hline 28. & & & & Rašačių k. & 10 \\
\hline 29. & & & & Dzegciorių k. & 12 \\
\hline 30. & & & & Stankūnų k. & 10 \\
\hline
\end{tabular}




\begin{tabular}{|c|c|c|c|c|c|}
\hline 31. & & & & Vidugirių Būdos k. & 10 \\
\hline 32. & & & & Vaičiuliškès k. & 15 \\
\hline 33. & & & & Musteikos k. & 14 \\
\hline 34. & & & & Pavalakès k. & 19 \\
\hline 35. & & & & Noškūnų k. & 10 \\
\hline 36. & & & & Aradnykų k. & 10 \\
\hline 37. & & & & Burbiškių k. & 10 \\
\hline 38. & & & & Bubelių k. & 10 \\
\hline 39. & 19390719 & 271 & & Mielagėnų k. & 14 \\
\hline 40. & & & & Krūminių k. & 24 \\
\hline 41. & 19390720 & 272 & 10 & Kreivènų k. & 9 \\
\hline 42. & & & & Punsko k. & 10 \\
\hline 43. & & & & Vaitakiemio k. & 10 \\
\hline 44. & & & & Šlynakiemio k. & 10 \\
\hline 45. & & & & Trakiškių k. & 10 \\
\hline 46. & & & & Ožkinių k. & 10 \\
\hline 47. & & & & Navinykų k. & 14 \\
\hline 48. & & & & Kampuočių k. & 12 \\
\hline 49. & & & & Vèlionių k. & 10 \\
\hline 50. & & & & Dotenènų k. & 10 \\
\hline 51. & 19390724 & 273 & 5 & Drucminų k. & 20 \\
\hline 52. & & & & Piliakalnio k. & 13 \\
\hline 53. & & & & Svylionių k. & 33 \\
\hline 54. & & & & Mištūnų k. & 16 \\
\hline 55. & & & & Strèžiūnų k. & 13 \\
\hline 56. & 19390728 & 274 & 14 & Viečiūnų k. & 10 \\
\hline 57. & & & & Zabarninkų k. & 12 \\
\hline 58. & & & & Zervynų k. & 14 \\
\hline 59. & & & & Ratnyčios k. & 10 \\
\hline 60. & & & & Pamerkio k. & 10 \\
\hline 61. & & & & Pelesos k. & 16 \\
\hline 62. & & & & Klevų k. & 10 \\
\hline 63. & & & & Lumbių k. & 10 \\
\hline 64. & & & & Neravų k. & 10 \\
\hline 65. & & & & Antalgès k. & 14 \\
\hline 66. & & & & Bieniūnų k. & 11 \\
\hline \multirow[t]{2}{*}{67.} & & & & Barčių k. & 10 \\
\hline & & & & Kapiniškių k. & $14^{\star *}$ \\
\hline 68. & & & & Krivilių k. & 17 \\
\hline 69. & 19390804 & 275 & 8 & Klaišių k. & 14 \\
\hline 70. & & & & Novosiolkų k. & 12 \\
\hline 71. & & & & Paditvio k. & 14 \\
\hline 72. & & & & Senųjų Druskininkų k. & 11 \\
\hline 73. & & & & Stašionių k. & 11 \\
\hline
\end{tabular}




\begin{tabular}{|c|c|c|c|c|c|}
\hline 74. & & & & Kalviškių k. & 10 \\
\hline 75. & & & & Pavainikių k. & 12 \\
\hline 76. & & & & Kargaudų k. & 12 \\
\hline 77. & 19390810 & 276 & 11 & Navasèdų k. & 15 \\
\hline 78. & & & & Radziūčių k. & 39 \\
\hline 79. & & & & Cesliukiškių k. & 11 \\
\hline 80. & & & & Vydenių k. & 14 \\
\hline 81. & & & & Kašètų k. & 12 \\
\hline 82. & & & & Šalčinių k. & 10 \\
\hline 83. & & & & Valinčių k. & 10 \\
\hline 84. & & & & Budvydonių k. & 12 \\
\hline 85. & & & & Sklodonių k. & 17 \\
\hline 86. & & & & Dieveniškių mstl. & 13 \\
\hline 87. & & & & Kozulių k. & 12 \\
\hline 88. & 19390816 & 277 & 32 & Rubežankos ir Naujasèdès k. & 10 \\
\hline 89. & & & & Dubinių k. & 11 \\
\hline 90. & & & & Rèkučių k. & 11 \\
\hline 91. & & & & Knystuškių k. & 10 \\
\hline \multirow[t]{2}{*}{92.} & & & & Kruklių k. & 19 \\
\hline & & & & Rudnios k. & $12^{\star *}$ \\
\hline 93. & & & & Rimdžiūnų k. & 14 \\
\hline 94. & & & & Marcinkonių mstl. & 10 \\
\hline 95. & & & & Petrikų k. & 10 \\
\hline 96. & & & & Galčiūnų k. & 23 \\
\hline 97. & & & & Gaigalų k. & 12 \\
\hline 98. & & & & Miciūnų k. & 17 \\
\hline 99. & & & & Miliūnų k. & 11 \\
\hline 100. & & & & Rimašių k. & 16 \\
\hline 101. & & & & Leliušių k. & 10 \\
\hline \multirow[t]{15}{*}{102.} & & & & Vaičiuliškès k. & 1 \\
\hline & & & & Krivilių k. & $3^{* *}$ \\
\hline & & & & Kapiniškių k. & $6^{*}$ \\
\hline & & & & Gaurelių k. & $13^{* * *}$ \\
\hline & & & & Geniūnų k. & $9^{* * *}$ \\
\hline & & & & Guntauninkų k. & $3^{* * *}$ \\
\hline & & & & Rudnios k. & $4^{* *}$ \\
\hline & & & & Pirčiupių k. & $5^{\star *}$ \\
\hline & & & & S. Naniškių k. & $3^{* *}$ \\
\hline & & & & Miežionèlių k. & $11^{* * *}$ \\
\hline & & & & Klevų k. & $4^{* *}$ \\
\hline & & & & Pavainikių k. & $2^{\star *}$ \\
\hline & & & & Pavalakès k. & $7^{\star *}$ \\
\hline & & & & Krokšlio k. & $1^{\star *}$ \\
\hline & & & & Veikūnų k. & $9^{* *}$ \\
\hline
\end{tabular}




\begin{tabular}{|c|l|l|l|l|c|}
\hline & & & & Švenčionèlių mstl. & $12^{* *}$ \\
\hline 103. & & & & Svylionių k. & $18^{* *}$ \\
\hline Iš viso & & & 103 skyriai & & Apie 1500 \\
\hline
\end{tabular}

\section{Paaiškinimai:}

* - tas pats skyrius su antrą kartą protokole ịrašytomis tomis pačiomis pavardėmis.

** - tas pats skyrius, protokole įrašytos ankstesniuose protokoluose minimos pavardès, tačiau yra ir nauju asmenų.

*** - jau anksčiau įregistruoto „Ryto“ skyriaus kaimo sąraše - priimti nauji asmenys.

1939 m. birželio 27 d. posėdyje ${ }^{38}$ nutarta ịvesti atskirus asmens lapelius narių registracijai (projektą parenge kun. K. Čibiras). Be to, iš „Ryto“ draugijos esamo narių sąrašo išbraukti 8 nariai (vieni mirę, kiti išvykę ị užsienį, dar kiti, - seniai nebemokantys mokesčio, - išstojo patys). Liepos $8 \mathrm{~d}$. ịkurtų skyrių veiklos sunkumus detalizavo kun. K. Čibiras ir pasiūle įvesti „Ryto“ draugijos nario pažymejjimą ${ }^{39}$.

Duomenys apie „Ryto“ draugijų skyrių steigiamuosius susirinkimus 1939 m. pateikti 3 lenteleje. Spartus naujų „Ryto“ draugijos skyrių kūrimasis rodo, kad žmonès buvo išsiilgę lietuviško rašto, savo kultūros, tradicijų ir papročių. Matyti, jog apie vienoje ar kitoje vietoveje ịvykusi steigiamąji „Ryto“ draugijos skyriaus susirinkimą buvo informuojama storastija, turejjusi patvirtinti įsteigtą skyrių ar dẻl tam tikrų priežasčių jo nepatvirtinti.

Toks spartus skyrių kūrimasis buvo svarbus akstinas oficialiai pripažinti „Ryto“ draugijos veiklą.

3 lentelè. „Ryto“ draugijų skyrių steigiamieji susirinkimai 1939 m. (sudaryta remiantis LMAVB RS F 67 - 264/3. L. 86 - 86 a. p.)

\begin{tabular}{|c|c|c|c|c|}
\hline $\begin{array}{l}\text { Eil. } \\
\text { nr. }\end{array}$ & Vietovės pavadinimas & Valsčius & $\begin{array}{l}\text { Steigiamojo } \\
\text { susirinkimo data }\end{array}$ & $\begin{array}{l}\text { Pranešimo } \\
\text { storastijai data }\end{array}$ \\
\hline 1. & Antalgè & Rimšè & Rugpjūčio $5 \mathrm{~d}$. & \\
\hline 2. & Dieveniškès & & Rugpjūčio $20 \mathrm{~d}$. & \\
\hline 3. & Duotènai & Švenčionys & & Rugpjūčio $1 \mathrm{~d}$. \\
\hline 4. & Dubičiai & Užbalis (?) & Liepos $16 \mathrm{~d}$. & \\
\hline 5. & Dzegcioriai & Valkininkai & Liepos $25 \mathrm{~d}$. & \\
\hline 6. & Gaigalai & Gervèčiai & Rugpjūčio 20 d. & \\
\hline 7. & Galčiūnai & Gervèčiai & Rugpjūčio 27 d. & \\
\hline 8. & Gaureliai & Kaltanènai & Rugpjūčio $13 \mathrm{~d}$. & \\
\hline 9. & Geniūnai & Valkininkai & Liepos $23 \mathrm{~d}$ & \\
\hline 10. & Grybai & Švenčionys & Liepos $23 \mathrm{~d}$. & Rugpjūčio $1 \mathrm{~d}$. \\
\hline 11. & Guntauninkai & Tverečius & Liepos $9 \mathrm{~d}$. & Liepos $10 \mathrm{~d}$. \\
\hline 12. & Juodiškès & Švenčionys & & Rugpjūčio 4 d. \\
\hline 13. & Kampuočiai & Seinai & Liepos $30 \mathrm{~d}$ & \\
\hline 14. & Kapiniškiai & Marcinkonys & Rugpjūčio $13 \mathrm{~d}$. & \\
\hline 15. & Kaziuliai & Dieveniškès & Rugpjūčio $13 \mathrm{~d}$. & \\
\hline 16. & Klevai & Krasnapolis & Rugpjūčio $13 \mathrm{~d}$. & \\
\hline
\end{tabular}




\begin{tabular}{|c|c|c|c|c|}
\hline 17. & Kreivėnai & Andrejavas & Liepos $24 \mathrm{~d}$. & \\
\hline 18. & Krokšlys & Varèna & Liepos $23 \mathrm{~d}$. & \\
\hline 19. & Margionys & Marcinkonys & Liepos $28 \mathrm{~d}$. & Liepos $29 \mathrm{~d}$. \\
\hline 20. & Mielagėnai & & Liepos $23 \mathrm{~d}$ & Rugpjūčio 1 d. \\
\hline 21. & Miciūnai & Gervéčiai & Rugpjūčio 27 d. & \\
\hline 22. & Miežionèliai & Švenčionys & Liepos 2 d. & Liepos $15 \mathrm{~d}$. \\
\hline 23. & Senosios Naniškès & Valkininkai & Liepos $9 \mathrm{~d}$. & Liepos $13 \mathrm{~d}$. \\
\hline 24. & Navinykai & Krasnavas & Liepos $26 \mathrm{~d}$. & \\
\hline 25. & Noškūnai & Varèna & Liepos $23 \mathrm{~d}$. & \\
\hline 26. & Papiškès & Valkininkai & Liepos $2 \mathrm{~d}$. & \\
\hline 27. & Pošalčiai & Valkininkai & Liepos $9 \mathrm{~d}$. & Liepos $13 \mathrm{~d}$. \\
\hline 28. & Pavainikès & Varèna & Rugpjūčio 18 d. & Rugpjūčio $22 \mathrm{~d}$ \\
\hline 29. & Pavalakè & Rodūnia & Liepos $30 \mathrm{~d}$ & Rugpjūčio 2 d. \\
\hline 30. & Piliakalnis & Rodūnia & Liepos $30 \mathrm{~d}$. & \\
\hline 31. & Senieji Ramonai & Andrejavas & Liepos $21 \mathrm{~d}$. & \\
\hline 32. & Rudnia & Varèna & Liepos $9 \mathrm{~d}$. & Liepos $12 \mathrm{~d}$. \\
\hline 33. & Svylionys & Adutiškis & Rugpjūčio 5 d. & \\
\hline 34. & Šaltiniai & Dieveniškès & Rugpjūčio 19 d. & \\
\hline 35. & Šlynakiemis & Seivai & Liepos $30 \mathrm{~d}$. & \\
\hline 36. & Švenčionèliai & & Liepos 2 d. & Liepos $17 \mathrm{~d}$. \\
\hline 37. & Vaičiuliškè & Andrejavas & Liepos $23 \mathrm{~d}$. & \\
\hline 38. & Vaitakiemis & Seivai & Liepos $23 \mathrm{~d}$. & \\
\hline 39. & Vèjinè & Kaltanėnai & Liepos $23 \mathrm{~d}$. & Rugpjūčio 4 d. \\
\hline 40. & Voriškès & Valkininkai & Liepos $23 \mathrm{~d}$. & \\
\hline
\end{tabular}

\section{4. „Ryto“ draugijos veiklos oficialus patvirtinimas}

1939 m. gruodžio 15 d. centro valdybos posėdyje kun. K. Čibiras, negalèdamas jame dalyvauti, pateikè raštišką to laikmečio ir „Ryto“ padèties apžvalgą, kurią perskaitè sekretorius kun. K. Pukènas (dokumentas publikuojamas pirmąsyk):

Beužsinešanti po uždarymo Ryto draugijos veikimą sustabdė kilęs š. m. rugsèjo 1 d. karas tarp Lenkijos ir Vokietijos, ir rugsejo 17 d. tarp Rusijos ir Lenkijos. Per karą suiro gyvenimas: vyrus sumobilizavo, atsirado namie daugiau ūkio ir valstybès darbo, sutriko susisiekimas, be to, draugijoms buvo uždrausta rodyti veiklumą. Skyrių organizavimai sustojo. Buvo organizuojama per 100 skyrių, buvusi vyriausybé juos iki paskutinių karo ịvykių traktavo nepalankiai, drausdama atidaryti dèl tokių mažmožių, kaip pav. kad valdybose yra narių iš buvusios Šv. Kazimiero draugijos narių, kad nesą garantijų iš valdybų sąstato, jog viešasis saugumas, ramybè ir tvarka nebus ardomi ir t. t.

Skyrių nè vienas nebuvo pradėjęs veikti, nes tik nežymiai jų daliai buvo išèjęs įsiteisinimo terminas ir tai paskutinèmis prieš karą dienomis.

Bolševikų kariuomenei įžygiavus ị Vilnių, draugija tiesa, užsiregistravo, bet veikti neturèjo jokių sąlygų, priešingai, buvo pagrindo laukti greito jos likvidavimo. 
Lietuvos kariuomenei spalio 28 d. išvadavus Vilniaus miestą ir kraštą, švietimo darbas nuejo kitais keliais ir daug Ryto dirbto darbo atiteko valstybei. Karo būklè, gyvenimo reorganizavimas, darbininkų peréjimas ił valstybinę tarnybą, registravimo formalumai ir lèšų klausimas sukèlé tiek keblumų, kad draugija veikti nepradejo.

Senieji Ryto darbininkai nuo lapkričio $1 \mathrm{~d}$. visi paleisti nuo tarnybos. Vytauto Didžiojo gimnazija išsilaisvino iš priklausomybès Rytui, tapdama valstybine gimnazija, nẻ vienas iš organizuojamų vasarą skyrių neatsiliepé norịs pradèti darbą, daugumą narių reikia laikyti nustojus būti nariais dèl išsiblaškymo jau dèl to, kad liko anapus sienos.

Naujas Vilniaus krašte padalijimas tarp Lietuvos ir SSSR labai skaudus Rytui, nes jis netenka žymios dalies (2/3) savo veikimo teritorijos ir daugelio labai judrių narių, netenka žmonių, su kuriais ir kuriems ilgus metus Rytas dirbo ir aukojosi.

Š. m. lapkričio 13 d. pranešta Vilniaus miesto ir apskrities viršininkui apie draugijos buvimą, ligšiolinę veiklą, turtą ir sąskaitą.

Š. m. lapkričio 18 d. paprašyta Švietimo Ministerijos Igaliotinio perleisti b. Vilniaus seminarijèlę darželietėms ruošti. Šio mènesio viduryje Ryto pirmininkas kalbejosi su Švietimo Ministerijos atstovu dir. Sobliu, kuris žadejo padèti laikyti skaityklas. ${ }^{40}$

Nustatytas delegatų, siunčiamų skyrių organizuojamoms savaitėms, skaičius (po vieną, o gausiems, per 30 narių turintiems skyriams - dar po vieną).

Kalbèta apie draugijos veiklos kryptis: skyrių, skaityklų organizavimą, paskaitas, kursus suaugusiesiems, darželiečių lavinimą.

Aptartas skolos klausimas: draugija skolinga Lenkų ūkio bankui (Bance Gospodarstwa Krajowego) $60000 \mathrm{zl}$ su užaugusiais procentais. Jei šios, lenkų smurtu užtrauktos skolos nebus galima likviduoti kokiu nors būdu, nuspręsta kreiptis į teismą ir prašyti advokatą Juknevičių vesti teisinę bylą. Nutarta parengti sąmatą ir prašyti vyriausybę duoti lèšu.

Dèl suvalstybintos Vytauto Didžiojo gimnazijos kreiptasi į Švietimo ministeriją, nes „Rytas“ apie tai jokio rašto negavo, sužinojo tik iš spaudos. Švietimo ministerija, gavusi „Ryto“ raštą, kreipèsi i gimnazijos direkciją, reikalaudama sudaryti turto sąrašą buvusioje gimnazijoje. Gimnazijos direkcija prašè „Rytą“ atsiųsti savo atstovą, kad būtų galima bendrai sudaryti sąrašą. „Kadangi neaišku ar Ministerija nori nusavinti ar išnuomoti ši turtą, nuspręsta tuo tarpu nesiųsti draugijos delegato “ ir šią padètị ištirti Ministerijoje ${ }^{41}$.

Nutarta artimiausiu laiku sušaukti visuotinị narių susirinkimą. Protokole pateikta ir 1940-1941 m. sąmata ${ }^{42}$.

\section{5. „Ryto“ ịsitvirtinimas $1939 \mathrm{~m}$. pabaigoje ir finansiniai sunkumai}

1939 m. gruodžio 15 d. posėdyje „Ryto“ draugijos valdyba svarstė statuto pritaikymą pasikeitusiomis sąlygomis ir jo užregistravimą pagal naujus Lietuvos įstatymų reikalavimus (ịstatuose pakeistas veikimo laikotarpis ir įrašyta pastaba apie globojamus 14-18 metų narius $)^{43}$. 
1939 m. gruodžio 16 d. kun. K. Pukėnas „Ryto“ draugijos steigèjų vardu kreipèsi ị vidaus reikalų ministrą, prašydamas leidimo draugijai dirbti, motyvuodamas tuo, kad „Ryto“ draugija ịkurta prieškariniais laikais, lenkų okupacijos laiku švietė ir sąmonino Vilniaus krašto gyventojus tautiškoj dvasioj. Atgavus laisvę kreipiamès jau pas savo vyriausybę leisti mūsų Draugijai ir toliau veikti mūsų Tẻvynès labui““44.

Kartu su įstatais, kurių pabaigoje adresai, parašai ir pavardès asmenų (pasirašè kun. Kazimieras Pukènas, Vincas Budrevičius, kun. Pranciškus Bieliauskas, Ignotas Budreika, Romualdas Bagdonas, Augustinas Burokas, Juozas Maceika, Leonas Golubickas, Jonas Šimukonis, Antanas Stancelis, Antanas Juknevičius, kun. Edmundas Basys) ${ }^{45}$, siekiančiu atkurti „Ryto“ draugiją (parašai patvirtinti Vilniaus notaro Juozo Platakio, 1939 m. gruodžio 16 d. rejestro Nr. 539) ${ }^{46}$, iteiktas ir kreipimasis.

Kreipimosi tekstas:

Mes, žemiau pasirašę, šiuo prašome įregistruoti Lietuvių švietimo „Ryto“ draugiją, kurios İstatus 3 egz. pridedame.

"Ryto“ draugija ịsteigta Vilniaus kraštui šviesti dar 1913 m. Rusų, vokiečių ir lenkų okupacijos laikais ji laikè pradžios ir vidurines mokyklas, o paskutiniaisiais lenkų viešpatavimo metais - skaityklas. Tuo darbu ji nori ir toliau verstis.

Mes visi pasirašę atitinkame visus Draugijų îstatymo 7 str. numatytus reikalavimus. Savo igaliotiniu draugijos registracijos reikalams skiriame kun. Krištapą Čibirą, jam duodame teisę keisti mūsų pasirašytus İstatus, jei tai būtų reikalinga registracijos sumetimais ${ }^{47}$.

Tačiau 1940 m. sausio 9 d. raštu Nr. 682, kuri pasirašé Lietuvos Respublikos VRM Spaudos ir draugijų skyriaus vedèjas D. Stankūnas bei draugijų referentas J. Kompaitis, „Ryto“ draugijos ịstatai buvo sugrąžinti ir išvardytos septynios dokumentų grąžinimo priežastys ${ }^{48}$. Atsižvelgus ị pateiktas pastabas ir papildžius ịstatus, jie buvo priimti ir patvirtinti.

Lietuvos Respublikos VRM Spaudos ir draugijų skyrius $1940 \mathrm{~m}$. vasario $22 \mathrm{~d}$. raštu Nr. 682 pranešè „Ryto“ valdybai, kad vidaus reikalų ministras $1940 \mathrm{~m}$. vasario $21 \mathrm{~d}$. patvirtino steigiamos Lietuvių švietimo „Rytas“ draugijos įstatus ir pagal juos leido draugijai veikti. $1940 \mathrm{~m}$. vasario $22 \mathrm{~d}$. „Ryto“ draugija buvo įrašyta ị Draugijų registrą Nr. 9357 (dokumentą pasirašè jau minèti D. Stankūnas ir J. Kompaitis) ${ }^{49}$. İstatuose surašytos steigejų pavardès (kun. Krištapas Čibiras, Vincas Budrevičius, Antanas Matulionis, Silvestras Urbonas, kun. Pranciškus Bieliauskas, Ignotas Budreika, kun. Vincentas Taškūnas, Konstantinas Stašys, adv. Antanas Jakučionis, Kazys Krikščiukaitis, kun. Rapolas Mackevičius ir kun. Kazimieras Pukènas) ir adresai ${ }^{50}$. Tad „Ryto" draugija vèl patvirtinta 1940 m. vasario 21 d., o 22 d. ịrašyta į Draugijų registrą (Nr. 9357).

Būtina pažymèti, kad, rengiant statutą ir ịstatus, 1939 m. gruodžio 14 d. (raštas Nr. 387) kartu buvo parengtas pareiškimas finansų ministrui Kaune, kuriame aiškinta, kokia veikla užsiima draugija nuo jos ịsikūrimo prieškario laikais ${ }^{51}$. Rašyta, jog okupantai lenkai pamažu varžè veiklą, o pirmas stambus smūgis - Mokytojų seminarijos ir daugelio mokyklų uždarymas 1927 m., paskatinęs tolesnị „Ryto" padalinių uždarymą. $1938 \mathrm{~m}$. sausio 29 d. sustabdžiusi „Ryto“ veiklą - uždariusi centrą - lenkų administracija draugijos turtą paèmé savo žinion. Lenkams itin rūpèjo „Ryto“ namai Antakalnio g. 6, tad paskirti 
lenkų kuratoriai juos įskolino bankui „Gospodarstwa Krajowego“ (60 000 zl). Nors „Ryto“ draugijos valdyba šį poelgị užprotestavo ir bylą padave ị teismą, bet iki pat Lenkijos žlugimo ji nebuvo svarstyta. Tad 1939 m. gegužès 20 d., kai „Rytas“ grịžo tikriesiems šeimininkams, lenkų administracija skolos klausimo neleido kelti. Valdyba nepasitenkinimą galëjo pareikšti tik žodžiu. Lenkų kuratoriai nesutiko atsiskaityti. „Kadangi ši paskola buvo užtraukta lenkų okupantų neteisètu keliu, kadangi šios paskolos „Rytas“ niekuomet nepripažino ir kadangi ši skola yra smurto ir persekiojimų vaisius, „Ryto“ valdyba maloniai prašo Poną Ministrą išbraukti viršminètą skolą su visais nuošimčiais", - baigia raštą už pirmininką kun. K. Čibirą pasirašęs kun. K. Pukènas ${ }^{52}$.

\section{6. „Ryto“ draugija $1940 \mathrm{~m}$.}

1940 m. kovo 8 d. vykusiame visuotiniame susirinkime pirmininkas kun. K. Čibiras apžvelgè draugijos veiklą $1939 \mathrm{~m}$. birželio 25 d. $-1940 \mathrm{~m}$. kovo 8 d. laikotarpiu ${ }^{53}$. Pažymejjo, kad draugijai teko susidurti su lenkų, rusų valdžiomis ir pagaliau 1939 m. spalio $28 \mathrm{~d}$. sulaukti savo vyriausybès ir pritaikyti ịstatus prie jos reikalavimų. „Laikotarpis pilnas nerimo, karo suirutès, visokių aimanų. Lenkams valdant buvo imtasi kaimuose steigti skyrius, jų buvo suorganizuota per 100, bet jų legalizacijai užtrukus, kilo karas ir jie savo veikla nepasireiškè. Lenkų vyriausybẻ nepalankiai traktavo skyrių steigimą: jei j̣ skyriaus valdybą įeidavo žmonès, kurie anksčiau buvo Šv. Kazimiero skyrių valdybose, netvirtindavo skyrių. Mobilizacijai ir karui prasidejus buvo sustabdytas visų draugijų veikimas. Kita vertus, vyriškajam jaunimui nuejjus ị kariuomenę, suiro kaimų gyvenimas ir neliko - kas veiktų. Rusų kariuomenei užèmus Vilnių taip pat nebuvo sąlygų veiklai. Draugija užsiregistravo ir lauké" ${ }^{\text {"54, }}$ - kalbèjo kun. K. Čibiras.

Lietuvos valstybei atgavus Vilnių iš pagrindų pasikeitè gyvenimo sąlygos, tad draugijai reikèjo persitvarkyti. Ji neteko savo buvusių tarnautojų (kai kurie ịstojo ị valstybinę tarnybą), neteko lèšu (iš Lietuvos visuomenès ịplaukdavusių lešų neliko, o naujų šaltinių nebuvo matyti). Be to, mokyklas ir skaityklas ėmé steigti ir tvarkyti pati vyriausybè.

Po draugijos narių visuotinio susirinkimo $1940 \mathrm{~m}$. kovo $12 \mathrm{~d}$. centro valdybos posèdyje pasiskirstyta pareigomis ${ }^{55}$ (žr. 1 lentelę).

Taupumo sumetimais pasiūlyta draugijos knygyną ir raštinę iš buto I aukšte perkelti ị butą IV aukšte. Mokytojui V. Budrevičiui pavestas „Ryto“ narių administravimas; kun. K. Gumbaragiui - sutvarkyti draugijos knygyną: atskirti archyvines draugijos knygas, knygas kitomis kalbomis.

1940 m. birželio 15 d. sovietų tankams užèmus Kauną ir Vilnių, Kremlius, kaip rašo Vytautas S. Vardys, pravedè sintetinę, šešias savaites trukusią revoliuciją, kuri pasibaigé rugpjūčio 3 d. formaliu Lietuvos inkorporavimu ị Sovietų Sajungą, o vèliau - jjungimu ¿̇ Maskvos imperiją ${ }^{56}$.

264/3 byloje yra 44-ios (šešių punktų) užpildytos anketos - prašymai priimti ị Lietuvių švietimo draugijos „Rytas“ narius rašyti draugijos centro valdybai. $1940 \mathrm{~m}$. kovo $2 \mathrm{~d}$. anketas užpilde kun. Karolis Gumbaragis, advokatas Fabijonas Kemėšis, Pedagoginio instituto lektorius kun. Alfonsas Lipnickas, pedagogè Ona Narušyte, Zuzana Stašienė ir kun. Nikodemas Vaišutis ${ }^{57}$. Kovo 4 d. - Konstantinas Stašys, kun. Juozas Vaičiūnas ${ }^{58}$. Itin 
daug anketų užpildyta kovo 8-ąją - anketas pateikė Romualdas Bagdonas, gimnazijos kapelionas kun. Edmundas Basys, kun. Pranas Bieliauskas, mokytojas Motiejus Bigelis, Petronèlè Bizokaite, tarnautojas Vincas Budrevičius, buhalteris Ignotas Budreika, savivaldybės valdininkas Augustinas Burokas, raštvedys Adomas Cicènas, gydytojas Stasys Čepulis, kun. Juozas Dubietis, tarnautojas Leonas Golubrinas, mokytoja Gertrūda Gudalaityte, notaras Stasys Jackus, advokatas Antanas Juknevičius, Konstancija Juknevičienè, „Vaidilos" teatro vadovas Juozas Kanopka, valdininkè Genovaitė Kisielytė, „Vilniaus balso" leidèjas Kazys Kriščiūnas, kun. Benediktas Krištaponis, buhalteris Antanas Matulionis, mokytojas Patras Mareckas, savivaldybės tarnautojas Kostas Miškinis, tarnautoja Barbora Motiejūnaite, mokytojas Jonas Naujelis, kun. Juozas Panavas, kapelionas kun. Kazimieras Pukenas, Anele Tastenyte, mokytoja Elžbieta Rimšaitè, teismo kandidatas Antanas Vaišnius, pirklys Andriejus Žemaitis-Žmuidzinas, Marija Žmuidziniené, bendrabučio vedejja Marija Žukauskaite ${ }^{59}$. Kovo 16 d. anketą užpildè mokytojas Adomas Butrimas, o 21 d. - mokytojas Feliksas Milis (Molis) ${ }^{60}$.

Galima manyti, kad šis anketų pildymas buvo papildomas, nes toje pačioje byloje esančiuose sąrašuose ne vieno asmens nurodytas įstojimo ị draugiją laikas - $1938 \mathrm{~m}$. gruodžio $11 \mathrm{~d} .{ }^{61}$.

Pareigybès, minimos anketose, liudija asmenų, turëjusių ịvairią profesiją, norą dirbti švietimo srityje Vilnijos krašte, o tai, jog iš 44-ių anketą užpildžiusių asmenų buvo 10 dvasininkų, paneigia teigini, esą „Rytas“ buvo „grynai klerikalinë“ organizacija.

Paskutinis valdybos posėdis. Nors carinès Rusijos, vokiečių ir lenkų okupacinè valdžia varžè ir netgi buvo sustabdžiusi draugijos „Rytas“ veiklą, draugija, reikia manyti, vis dèlto tikejjosi galèsianti kokiu nors būdu tęsti veiklą. Tai liudija ir „Ryto“ draugijos fonde esantis svarbus dokumentas $-1940 \mathrm{~m}$. liepos $6 \mathrm{~d}$. vykusio posėdžio protokolas ${ }^{62}$. Posédyje nedalyvavo tik kun. K. Gumbaragis - žr. 1 lentelę. Valdybos nariai svarste 12 klausimų, be to, labai plačiai bei detaliai buvo apžvelgta tuomete „Ryto“ draugijos padètis, planai ir kliuviniai. Pravartu nuodugniau aptarti paskutinị nagrinėjamo laikotarpio Lietuvių švietimo draugijos „Rytas“ posedi, nes tai vienintelis šaltinis, kuriame plačiai apžvelgta to meto „Ryto“ politiné, ekonominé padètis, pastangos sustiprinti „Ryto" draugiją ir plèsti jos veiklą, nors tos pastangos ir nedave laukiamų rezultatų.

Pirmininkas K. Čibiras pranešè, kad Lietuvos teismai atidave draugijos kasos knygas ir dokumentus, kuriuos buvo paėmusi lenkų vyriausybe draugijos persekiojimo ir uždarymo metu.

Visas draugijos turtas perkeltas ị naujas patalpas IV aukšte. Knygų katalogai, sudaryti prieš uždarant „Rytą“, neteko aktualumo, o naujiems sudaryti stigo lešų. Knygų daug, o kraustantis iš patalpos ị patalpą ir lenkams darant revizijas jos sumaišytos. Per trumpą laiką atrinktos tinkamos skaitykloms, bet nèra sukataloguotos.

Draugijos centro valdybos sekretorius rūpinosi „Ryto“ archyvu. Iki minèto posèdžio per trumpą laiką gauta daug prašymų (buvusių tarnautojų ir Mokytojų seminarijos auklètinių) dèl pažymėjimų apie tarnybos laiką. Pažymèjimai buvo reikalingi švietimo ìstaigoms (siekiant nustatyti tarnybos laiką ar tarnautojo cenzą) ir dalyti dovanai.

Draugijos namuose suremontuoti du butai (namas per rudens suirutę buvo apleistas senụjų nuomininkų ir išnuomotas naujiems gyventojams). Mokslo draugija už 
nuomojamas patalpas nuomos nemokejjo jau nuo praejjusių metų rudens, taip pat nemokejjo iš kuratorių laikų (lenkų okupacinès valdžios laikotarpio) užsilikusios skolos aiškinosi neturinti lešų. Skolingas už nuomą buvo ir dailininkas Rapolas Jakimavičius (1893 1020 - 196102 19), nes ilgą laiką neturejjo jokių pajamų.

Dèl lenkų bankui kuratoriaus paliktos hipotetinès 60000 zl skolos K. Čibiras raštu, o vèliau ir asmeniškai kreipèsi ị Finansų ministeriją, bet per pasikalbejjimus paaiškejjo, kad Finansų ministerija nesijaučia galinti skolą anuliuoti ir siūlo teismo procedūrą. Tačiau bylai iškelti reikia didelių sumų advokatui, pačiam teismui, skaičiuojant procentus nuo ginčijamos sumos, o draugijos kasa tuščia. Tad šis klausimas paliktas atviras.

Draugija, siekdama plètoti veiklą, tikejjosi dvasininkijos pagalbos. Ketindama steigti skaityklas, kreipèsi raštu ị lietuviškų parapijų klebonus, prašydama juos savo parapijoje suorganizuoti skyrius, skaityklas. Ieškant šiam darbui lěšų, 1940 m. balandžio 14 d. Vyriausybès igaliotiniui ministrui Kaziui Bizauskui (1893 0214 - 194106 26) buvo ịteiktas motyvuotas prašymas ir sąmata.

Dèl subsidijų „Ryto“ skaitykloms du kartus kreiptasi i Švietimo ministeriją, bet ten paaiškinta, kad ministerija pati nebaigè organizuoti savo skaityklų ir neturi laisvų lèšų, tad „Ryto“ draugija šimet lèšu negaus.

1940 m. birželio 7 d. sudarytas „Ryto“ draugijai priklausiusios Vytauto Didžiojo gimnazijos kilnojamojo turto ir knygyno perdavimo-priëmimo aktas. Gimnazijos direktoriaus sudaryta komisija ịvertino visą perduodamą turtą, sudare jo sąrašą. Gimnazijos inventorius ịvertintas 26 465,65 Lt, knygynas - 9849,30 Lt, iš viso 36314 Lt 95 ct.

Gautas raštas iš Vilniaus m. viršininko, kad draugijos veikla sustabdoma ir iki liepos $8 \mathrm{~d}$. dèl tolesnès veiklos reikia įteikti Vidaus ministerijai prašymą. Informuojama, jog toks prašymas išsiųstas jau liepos $3 \mathrm{~d}$.

Iš II mokesčių inspekcijos draugija gavo įsakymą sumokèti 938 Lt 40 ct mokesčio. Valdyba nutarè dalị mokesčių, t. y. 469 Lt 20 ct, sumokèti ir siųsti prašymą, kad mokestis draugijai būtų sumažintas.

Nutarta prašyti Švietimo ministerijos, kad sumokètų draugijai sumą, priklausančią už perduotą Vytauto Didžiojo gimnazijai kilnojamąjt turtą. Gautus pinigus panaudoti skolai, likusiai iš kuratelès laikų, panaikinti.

Paskutiniame posėdyje ị draugiją buvo priimti du nariai: Adomas Butrimas ir Feliksas Milis (Molis).

Tačiau visą planuotą „Ryto“, kaip ir kitų katalikiškų organizacijų Lietuvoje, veiklą radikaliai pakeitè 1940 m. vasarą prasidejjusi krašto sovietizacija. 1940 m. padèti Lietuvoje yra nagrinèję dr. Arūnas Streikus, Vytautas S. Vardys ${ }^{63}$, tad galima remtis jų teiginiais. $1940 \mathrm{~m}$. birželio 26 d. Liaudies vyriausybè nutarè vienašališkai nutraukti Lietuvos Respublikos ir Vatikano pasirašytą konkordatą (1927 m.), saugojusi nuo nepagrịsto pasaulietinès valdžios kišimosi ị Bažnyčios reikalus. Birželio $27 \mathrm{~d}$. neteisètomis paskelbtos visos religinès organizacijos, tą pačią dieną Švietimo ministerija išbraukè iš mokyklinių programų bet kokị tikybos dèstymą, mokyklose uždraudè maldas ir religinius simbolius, atleido mokyklų kapelionus (vèliau atleisti ir kitų institucijų kapelionai - panaikintas jų statusas). Lietuvos komunistų partija 1940 m. birželio 29 d. pareikalavo atskirti Bažnyčią nuo valstybès, uždarytas VDU Teologijos-filosofijos fakultetas (liepos 16-ąją sustabdyta jo veikla, 
o rugpjūčio 19 d. atleista visa fakulteto profesūra, be naujo darbo garantijos), uždrausta religinių organizacijų veikla - Bažnyčia buvo beveik visiškai išstumta iš viešojo gyvenimo.

Lietuvių švietimo draugija „Rytas“, 1939 m. gegužè 20 d. panaikinus veiklos draudimą, pasikeitus politinei situacijai, vèl patvirtinta $1940 \mathrm{~m}$. vasario $21 \mathrm{~d}$. (22 d. ̨̧rašyta ị Draugijų registrą), galèjo veikti tik kelis mènesius - sovietinei valdžiai, kovojusiai prieš Bažnyčią, religinio pobūdžio organizacijos kèle pavojų. Prie jų buvo priskirtas ir „Rytas“, todèl draugiją reikèjo sunaikinti - uždrausti veiklą.

\section{Išvados}

Lietuvių švietimo draugija „Rytas“, veikusi Vilnijos krašte, prasmingai ịsiliejo ị Lietuvoje jau veikusių „Žiburio“ (Suvalkijoje) ir „Saulès“ (Aukštaitijoje) draugijų veiklą. Draugijos atliko didžiulį darbą tautos švietimo, religinio ir tautinio sąmoninimo procese. Lietuvių švietimo draugijos tapo svarbiais lietuvių katalikiškąjį intelektinị sąjūdị vienijančiais centrais.

Nuo pat „Ryto“ ịsikūrimo (1913 m. sausio 31 d.) ịvairios okupacinès valdžios ribojo draugijos veiklą. Ypač aktyviai veikè lenkų okupantai: uždarinëjo mokyklas, bibliotekasskaityklas, mokymo kursus, pedagogams kliudè dirbti mokyklose. „Ryto“ veikla nuo pat pradžių buvo prieštaravimo, o vèliau ir neapykantos objektas.

Vilniaus miesto storastija $1938 \mathrm{~m}$. sausio 29 d. sustabdè „Ryto“ draugijos veiklą, o po mènesio, $1938 \mathrm{~m}$. vasario 28 d., Vilniaus vaivadija ją uždare - tai šio lenkų valdžios laipsniškai naikinto lietuvybès židinio galutinis rezultatas.

„Ryto" valdybos narių politinị jžvalgumą, savo egzistencinès padèties numatymą liudija jų sumanumas - draugijos turimos knygos, archeologiniai rinkiniai, archyvinè medžiaga ir inventorius buvo padovanoti Lietuvių mokslo draugijai.

Sustabdžius „Ryto“ draugijos veiklą, jos valdyba 1938 m. kovo 14 d. dèl pateiktų priekaištų nepagrịstumo raštu kreipèsi į Vidaus reikalų ministeriją, tačiau atsakymo į raštąskundą sulaukè tik $1939 \mathrm{~m}$. birželio $6 \mathrm{~d}$. „Ryto“ draugijos centro valdybos pastangomis 1939 m. gegužès 20 d. „Ryto“ veiklos draudimas panaikinamas, o birželio 6 d. perduotas (sugrąžintas), bet jau su didelemis skolomis, draugijai priklausęs turtas.

Nuo 1939 m. vidurio prasideda paskutinis prieškaryje veikusios „Ryto“ draugijos laikotarpis, kuris tęsiasi iki $1940 \mathrm{~m}$. vasaros - tada "Rytą" sunaikino sovietų okupacinè valdžia. Šios paskutinès prieškaryje veikusios „Ryto“ draugijos valdybą sudare kun. K. Čibiras (pirmininkas), dr. M. Šikšnys (vicepirmininkas), V. Budrevičius (iždininkas), kun. K. Pukenas (sekretorius) bei valdybos nariai: K. Stašys, A. Juknevičius ir R. Mackevičius (Mackonis).

Atsikūrusioji „Ryto“ draugija, nors ją itin neigiamai paveikè Vilnijos krašto padalijimas, pradèjo intensyvią veiklą burdama lietuvius, siekdama sudaryti sąlygas lietuvybès plètrai, mokyklų kūrimui.

„Rytas“ patvirtino ịvairius planus žinių sklaidai apie draugiją, skyrių, skaityklų steigimą, kursų organizavimą skyrių vadovams ir skaityklų vedejjams, darbą jaunimo auklèjimo bei švietimo srityje. Deja, prieškario laikotarpiu nebuvo atlikta didesnių darbų, nebespèta igyvendinti priimtų planų - „Ryto“ egzistencijos laikas buvo labai apribotas. 
„Ryto“ draugijos indèlị ì švietimo politiką, jos atliktų darbų svarbą liudija Vytauto Didžiojo gimnazijos (ją globojo draugija) ir dalies skaityklų suvalstybinimas.

Lietuvių švietimo draugijos „Rytas“ atlikti darbai Vilnijos krašte, puoselëjant lietuvybę, plètojant švietimą ir kultūrinị gyvenimą, skatino saugoti ši kraštą nuo nutautinimo.

\section{NUORODOS}

1 Prie dvasininkų pavardes rašomos trys ar keturios datos: gimimo, įšventinimo ị kunigus ir mirties (jei vyskupas - dar ir konsekracijos data).

2 Pauliukonis $P$. Tèvynès sargas // Lietuvių enciklopedija. Boston: Lietuvių enciklopedijos leidykla. 1964. T. 31. P. 121.

3 „Žiburio“ draugija - pirmoji Lietuvoje legalizuota draugija Užnemunèje. Būsimojo Telšių vyskupo Justino Staugaičio (1866 $1104-18900624-19260405$ - 19430708$)$ iniciatyva $1906 \mathrm{~m}$. sausio 6 d. Marijampolèje ịvyko steigiamasis susirinkimas. Kunigas parašè draugijos, pavadintos „Žiburiu“, ịstatus, kuriuose aiškiai pabrèžtas katalikiškas lietuviškos draugijos pobūdis. Per steigiamąji susirinkimą ị draugiją įsirašè 86 nariai. Reikalaujant draugiją uždaryti, katalikai kreipèsi ì gubernatorių ir 1906 m. gegužès 28 d. buvo užregistruoti „Žiburio“ įstatai, be to, išsirūpintas leidimas mokyklai ir vakariniams kursams. „Žiburio“ draugijos pirmininku išrinktas J. Staugaitis, jis šias pareigas ejo apie pusę metų, kol iš Marijampolès išvyko ị Lekéčius ten kurti naujos parapijos.

„Žiburio“ draugija buvo ịkurta kaip atsvara pirmeivių „Šviesos“ draugijai (1905-1908), kuri pirmoji pradejo steigti mokyklas, tačiau ị jas neįsileisdavo dvasininkų.

„Žiburio“ draugijos ịstatai leido jai veikti visoje Suvalkijoje. Tad parapijose veikiai kūrèsi skyriai (iki karo jų buvo 53). Daugelis skyrių turejjo lietuviškas pradžios mokyklas, senelių prieglaudas, knygynus.

„Žiburys“ pirmas Lietuvoje ịsteige 4 klasių mergaičiu progimnaziją, kurioje pamokos vyko lietuvių kalba. Mokyklos direktoriaus pareigas èjo kun. Motiejus Gustaitis (1870 0227 - 18870311 192712 23). Progimnazija turèjo internatą. Bendrabučio vedèja ir direktoriaus padejeja kurị laiką dirbo V. Liorentaité, vèliau pakviesta Marija Pečkauskaitè-Šatrijos Ragana (1877 0308 - 193007 24), dirbusi iki Pirmojo pasaulinio karo.

4 „Saulès“ draugija ịkurta Kaune 1906 m. rugpjūčio 7 d. kun. K. Olšausko, P. Januševičiaus ir kitų pastangomis. Draugija veikè Kauno gubernijoje. Ginčai dẻl privačių mokyklų paaštrejo $1929 \mathrm{~m}$. suvalstybinus kai kurias mokyklas.

5 „Ryto“ draugija - tai Vilniaus miesto ir Vilniaus krašto Lietuvių švietimo draugija „Rytas“ (toliau vartojamas trumpinys „Ryto“ draugija), su pertrauka veikusi 1913-1940 m.

6 „Draugija“ - mokslo, literatūros ir politikos žurnalas - buvo leidžiamas 1907-1940 m. (èjo 1907-1914; 1919-1933 ir 1937-1940). Nuo 1938 m. „Draugija“ - religijos ir kultūros dvisavaitinis žurnalas. Iki 1923 m. (išleisti 28 tomai) jis spausdintas Saliamono Banaičio spaustuveje. Leido Šv. Kazimiero draugija. Teologijos-filosofijos fakultetui ją pasirinkus savo organu nuo $1923 \mathrm{~m}$. pradedama nauja serija (nuo T. 1). Prie „Draugijos“ ịvairiu metu leisti priedai: „Ateitis“ (jos priedas „Žiedai - Mūsų tautinès tverybos" - išleisti 2 nr.); „Mokytojas“ - išleista 12 numerių; „Bažnyčios vadų žodis“ 1939 ir 1940 m.; „Gyvojo žodžio tarnyboje“ (1940 m. - 9 numeriai). Žurnale bendradarbiavo per 150 autorių. „Buvo aptariami literatūros, mokslo, politikos reikalai, bažnyčios ir teologijos dalykai, nagrinejjami literatūros kritikos, kultūros ir visuomenès gyvenimo klausimai, spausdinamos recenzijos, poezijos ir prozos kūriniai." (http://www.literatura.lt/enciklopedija/. Žiūrèta 2013-01-10)

7 Vieštautas P. Lietuvių švietimo draugija „Rytas“. Vilnius: „Vilniaus varpo“ leidinys Nr. 2. 1927.

8 Šikšnys M. Kunigas Petras Kraujalis - „Ryto“ draugijos pirmininkas // Kunigas Petras Kraujalis. Vilnius: Vilniaus lietuvių švietimo „Rytas“ draugija. 1937. P. 41-55.

9 Kuzmaitè J. Vilniaus „Ryto“ lietuvių švietimo draugija // Mokslo, kultūros ir švietimo draugijos. Iš lietuvių kultūros istorijos. Vilnius: Mokslas. 1975. P. 119-151. 
10 Vasiliauskienè A., Kareniauskaitè R., Zalogienè J., Zaloga E. „Ryto“ veiklos atspindžiai periodikoje: kunigas Mečislovas Reinys // Vilniaus kultūrinis gyvenimas: draugijų reikšmė 1900-1945 / sud. A. Lapinskienè. Vilnius: Lietuvių literatūros ir tautosakos institutas. 2008. P. 188-213.

11 Bruzgys A. Aš - mano žmogus. Morkus. Ryto draugijai - 100 metų: Morkaus Bruzgio (Bruzg, Bruzgès) 120-tosioms metinèms 1881(85)-1943(44) paminèti. Vilnius: Rotas (leidimo metai nenurodyti).

12 „Ryto“ draugijos fondas Nr. 67 (toliau - LMAVB RS F 67) // Lietuvos mokslų akademijos Vrublevskių bibliotekos Rankraščių skyrius.

13 Posėdžių protokolai rašyti ị liniuotų (33 eilutès) lapų knygą, kurioje jie numeruoti (100). Iš jų tik 49 prirašyti (rašyta abiejose lapo pusėse, išskyrus 47 lapą). Knyga ịrišta. Medžiaginè nugarèlè ir trikampiai kampučiai (dažyta vyšninès spalvos drobė). Viršelis padengtas margu kartonu. Viršelio viduryje priklijuotas mašinèle spausdintas lapas: „Lietuvių Švietimo „Ryto“ draugijos PROTOKOLŲ KNYGA. Pradèta 1936 m. kovo mèn. Baigta "(data nenurodyta).

Priekinio viršelio viršuje, kairèje pusėje, inventorinis numeris: „Lietuvos Mokslų Akademijos BIBLIOTEKA. F 67 - 264/5“.

14 „Ryto“ draugijos pirmininkai: 19130113 - 19150414 - dr. kun. Jonas Steponavičius (1880 0310 1906-1947 12 08); 19150414 - 19151108 - Juozas Kairiūkšis (1855 0305 - 19370614$)$; 19151108 - 19161213 - dr. kun. Mečislovas Reinys (18840203 - 19070610 - 19260405 19531108 ); 19161213 - 19180830 - Aleksandras Stulginskis (1885 0226 - 196909 22); antrą kartą pirmininko pareigoms išrinktas kun. dr. M. Reinys jas èjo 19180830 - 19220619 iki išvykimo ị Kauną. 19220619 - 19330814 pirmininku dirbo kun. Petras Kraujalis (1882 0708 1907 - 193308 14), po jo mirties „Ryto“ draugijos pirmininku išrinktas kun. Krištapas Čibiras (1888 1214 - 19140531 - 19420323$)$ šias pareigas èjo 19330814 - 19380228 ir 19390520 194007 08. Atkūrus „Ryto“ draugiją, nuo atkūrimo pradžios - 2004 m. balandžio 3 d. - jai vadovauja Algimantas Masaitis.

151938 m. sausio 13 d. posėdžio protokolas Nr. 264 // LMAVB RS F 67 - 264/5. L. 11.

161939 m. birželio 6 d. posèdžio protokolas Nr. 265 // LMAVB RS F 67 - 264/5. L. 11 a. p.

171938 m. sausio 13 d. posėdžio protokolas Nr. 264 // LMAVB RS F 67 - 264/5. L. 11.

181937 m. birželio 9 d. posèdžio protokolas Nr. 260 // LMAVB RS F 67 - 264/5. L. 7 a. p. -8.

191937 m. lapkričio 26 d. posėdžio protokolas Nr. 263 // LMAVB RS F 67 - 264/5. L. 10 a. p.

201939 m. birželio 6 d. posėdžio protokolas Nr. 265 // LMAVB RS F 67 - 264/5. L. 11 a. p.-12; F 67 264/1. L. 4.

211939 m. birželio 24 d. posèdžio protokolas Nr. 266 // LMAVB RS F 67 - 264/5. L. 13-13 a. p.

22 Lietuvių mokslo draugijai nuo $1939 \mathrm{~m}$. sausio $11 \mathrm{~d}$. buvo leista veikti kitu pavadinimu - Lietuvių mokslo mylètojų draugija.

231939 m. liepos 8 d. posėdžio protokolas Nr. 268 // LMAVB RS F 67 - 264/5. L. 17 a. p. -22.

241939 m. rugpjūčio 16 d. posèdžio protokolas Nr. 277 // LMAVB RS F 67 - 264/5. L. 38-45 a. p.

25 Ten pat.

261939 m. birželio 24 d. posėdžio protokolas Nr. 266 // LMAVB RS F 67 - 264/5. L. 13 a. p.-15 a.p.

271939 m. birželio 27 d. posėdžio protokolas Nr. 267 // LMAVB RS F 67 - 264/5. L. 16 a. p. -17 a. p.

281939 m. liepos 8 d. posėdžio protokolas Nr. 268 // LMAVB RS F 67 - 264/5. L. 17 a. p. -22.

291939 m. liepos 13 d. posédžio protokolas Nr. 269 // LMAVB RS F 67 - 264/5. L. 22 a. p.

301939 m. liepos 16 d. posèdžio protokolas Nr. 270 // LMAVB RS F 67 - 264/5. L. 23-25.

311939 m. liepos 19 d. posėdžio protokolas Nr. 271 // LMAVB RS F 67 - 264/5. L. 25 a. p.-26.

321939 m. liepos 20 d. posėdžio protokolas Nr. 272 // LMAVB RS F 67 - 264/5. L. 26 a. p.-28.

331939 m. liepos 24 d. posėdžio protokolas Nr. 273 // LMAVB RS F 67 - 264/5. L. 28 a. p.-30.

341939 m. liepos 28 d. posėdžio protokolas Nr. 274 // LMAVB RS F 67 - 264/5. L. 30-33.

351939 m. rugpjūčio 4 d. posèdžio protokolas Nr. 275 // LMAVB RS F 67 - 264/5. L. 33-34 a. p.

361939 m. rugpjūčio 10 d. posèdžio protokolas Nr. 276 // LMAVB RS F 67 - 264/5. L. 35-37 a. p.

371939 m. rugpjūčio 16 d. posèdžio protokolas Nr. 277 // LMAVB RS F 67 - 264/5. L. 38-45 a. p. 
381939 m. birželio 27 d. posėdžio protokolas Nr. 267 // LMAVB RS F 67 - 264/5. L. 16 a. p. -17 a. p.

391939 m. liepos 8 d. posèdžio protokolas Nr. 268 // LMAVB RS F 67 - 264/5. L. 17 a. p.-22.

401939 m. gruodžio 15 d. posėdžio protokolas Nr. 278 // LMAVB RS F 67 - 264/5. L. 45-46.

411940 m. sausio 10 d. posèdžio protokolas Nr. 279 // LMAVB RS F 67 - 264/5. L. 46 a. p.-47.

42 Pajamos 60000 litų (iš namų Vilniuje - 7460 Lt; nario mokesčio - 400 Lt; aukų ir pajamų iš loterijų, vaidinimų - $1000 \mathrm{Lt}$; pašalpos iš Vyriausybès iždo - $51140 \mathrm{Lt}$ ); išlaidos 60000 litų (namų laikymas - $6620 \mathrm{Lt}$; reikalų vedèjui (po 300) - $3600 \mathrm{Lt}$; 10 skaityklų vedejjams (po 60) - 7200 Lt; 5 skaityklų vedèjams (po 150) - 9000 Lt; 5 skaityklų vedèjams (po 180) - 10000 Lt; skaityklų butų nuoma (20 skaityklų po $20 \mathrm{Lt})$ - $4800 \mathrm{Lt}$; kuras, šviesa $(20 \mathrm{x} 20)$ - $4800 \mathrm{Lt}$; baldams - $1200 \mathrm{Lt}$; skaityklų knygoms, laikraščiams - 10800 Lt; „Ryto“ raštinei - 480 Lt; kelionių išlaidoms - 360 Lt; nenumatytiems reikalams - $340 \mathrm{Lt}$ ).

431939 m. gruodžio 15 d. posėdžio protokolas Nr. 278 // LMAVB RS F 67 - 264/5. L. 46-46 a. p.

44 Ponui Vidaus Reikalų Ministrui. Ryto draugijos steigejjų Prašymas // LMAVB RS F 67 - 264/4. L. 13.

45 LMAVB RS F 67 - 264/4. L. 41-52 (41-44, 45-48, 49-52).

46 LMAVB RS F 67 - 264/4. L. 41-52 (41-44, 45-48, 49-52).

47 Vidaus Reikalų Ministerijai // LMAVB RS F 67 - 264/4. L. 28.

48 1). Prašymas nepasirašytas 12 -kos steigèjų ir neapmokètas žyminiu mokesčiu; 2). Iš prašymo neaišku, ar Steigèjai atitinka Draugijų ịstatymo 7 straipsnio (Vyr. žin. 522) reikalavimus; 3). Prašyme nenurodytas draugijos steigejų ịgaliotinis (Draugijų ịstatymo 8 str.); 4). İstatai surašyti negryna ir netaisyklinga lietuvių kalba (Taisyklių draugijų įstatymui vykdyti 8 str. Vyr. žin. 553) ir, be to, yra daug netikslumų ir neaiškių dalykų apibūdinimų; 5). İstatų $\$ \$ 23$ ir 27 p.f prieštarauja Draugijų ịstatymui, nes ịstatai numato narius nuo 14 metų amžiaus (nariu gali būti tik nuo 18 metų) ir paveda padaliniams daryti turtinius aktus, nors padaliniai pagal Draugijų ịstatymą nėra teisiniai asmens ir neturèdami teisumo tokių aktų daryti negali; 6). İstatų $\$ 1$ turi būti nurodytas pilnas draugijos pavadinimas; 7). İstatų IV skyriuje per siaurai apibūdinta, kas gali būti draugijos nariu. Žr. Lietuvos Respublikos VRM Spaudos ir draugijų skyriaus 1940 m. sausio 9 d. raštas Nr. 682 // LMAVB RS F 67 - 264/4. L. 12.

49 Lietuvos Respublikos VRM Spaudos ir draugijų skyriaus 1940 m. vasario 22 d. raštas // LMAVB RS F 67 - 264/4. L. 15.

50 Lietuvių švietimo „Rytas“ draugijos İstatai // LMAVB RS F 67 - 264/4. L. 16-26.

51 Ponui Finansų Ministrui Kaune Pareiškimas. Gruodžio 14 d. 1939. Nr. 389 // LMAVB RS F 67 264/4. L. 14.

52 Ten pat. LMAVB RS F 67 - 264/4. L. 14.

53 Lietuvių švietimo Ryto draugijos visuotinio susirinkimo, ịvykusio 1940 metų kovo mèn. 8 dieną Vilniaus Šv. Mikalojaus b. saleje protokolas // $1940 \mathrm{~m}$. kovo $8 \mathrm{~d}$. visuotinis protokolas // LMAVB RS F 67 - 307/2. L. 34 a. p. - 36.

54 Ten pat.

551940 m. kovo 12 d. posėdžio protokolas Nr. 280 // LMAVB RS F 67 - 264/5. L. 48.

56 Krikščionybè Lietuvoje / red. V. S. Vardys. Čikaga: Lietuvos krikščionybès jubiliejaus komitetas. 1997. P. 367.

57 Lietuvių švietimo Rytas draugijos valdybai pareiškimas // LMAVB RS F 67 - 264/3. L. 43-48.

58 Lietuvių švietimo Rytas draugijos valdybai pareiškimas // LMAVB RS F 67 - 264/3. L. 49-50.

59 Lietuvių švietimo Rytas draugijos valdybai pareiškimas // LMAVB RS F 67 - 264/3. L. 51-83.

60 Lietuvių švietimo Rytas draugijos valdybai pareiškimas // LMAVB RS F 67 - 264/3. L. 84, 85.

61 Dokumentas neįvardytas - tai 30 asmenų pavardžių lentelè // LMAVB RS F 67 - 264/3. L. 9292 a. p.

621940 m. liepos 6 d. posèdžio protokolas Nr. 281 // LMAVB RS F 67 - 264/5. L. 48-49 a. p.

63 Streikus A. Sovietų valdžios antibažnytinè politika Lietuvoje (1944-1990). Vilnius: Lietuvos gyventojų genocido ir rezistencijos tyrimo centras. 2002. P. 40-60; Krikščionybė Lietuvoje. Ten pat. P. 367-388. 


\section{LITERATŪRA IR ŠALTINIAI}

\section{Archyviniai šaltiniai}

1. Lietuvių švietimo draugijos „Ryto“ Statutas. „Ruch“ spaustuvè. Totorių g-vè 6 (leidimo metai nenurodyti) // LMAVB RS F 67 - 264/4. L. 59-70.

2. „Ryto“ draugijos fondas Nr. 67 (LMAVB RS F 67): LMAVB RS F 67 - 57/2; LMAVB RS F 67 - 264/1; 264/2; 264/3; 264/4; 264/5; LMAVB RS F 67 - 307/2 // Lietuvos mokslų akademijos Vrublevskių bibliotekos Rankraščiu skyrius.

3. Statut Litewskiego T-wa Oswiatowego "Rytas” (Poranek). Druk. „Ruch“. Wilno, Tatarska 6 // LMAVB RS F 67 - 264/4. L. 55, 56, 57.

4. Statuten des Vereins "Rytas" ("Morgen") fur allgemeine Fortbildung unter den Lithauern. Wilna. 1915 // LMAVB RS F 67 - 264/4. L. 87-92 ir L. 93-98.

\section{Literatūra}

1. Eretas J. Dvi generacijos mūsų krikščioniškosios kultūros tarnyboje. Nuo „Tẻvynès sargo“ įsteigimo (1896) iki „Naujosios Romuvos“ ikūrimo (1931) // Lietuvių katalikų mokslo akademijos suvažiavimo darbai. Roma. 1972. T. 7.

2. Krikščionybė Lietuvoje / red. V. S. Vardys. Čikaga: Lietuvos krikščionybès jubiliejaus komitetas. 1997.

3. Kuzmaite J. Vilniaus „Ryto“ lietuvių švietimo draugija // Mokslo, kultūros ir švietimo draugijos. Iš lietuvių kultūros istorijos. Vilnius: Mokslas. 1975. P. 119-151.

4. Pauliukonis P. Tẻvynès sargas // Lietuvių enciklopedija. Boston: Lietuvių enciklopedijos leidykla. 1964. T. 31.

5. Streikus A. Sovietų valdžios antibažnytinè politika Lietuvoje (1944-1990). Vilnius: Lietuvos gyventojų genocido ir rezistencijos tyrimo centras. 2002.

6. Šikšnys M. Kunigas Petras Kraujalis - „Ryto“ draugijos pirmininkas // Kunigas Petras Kraujalis. Vilnius: Vilniaus lietuvių švietimo „Rytas“ draugija. 1937. P. 41-55.

7. Vasiliauskienè A., Kareniauskaitè R., Zalogiené J., Zaloga E. „Ryto“ veiklos atspindžiai periodikoje: kunigas Mečislovas Reinys // Vilniaus kultūrinis gyvenimas: draugijų reikšmė 1900-1945 / sud. A. Lapinskienè. Vilnius: Lietuvių literatūros ir tautosakos institutas. 2008. P. 188-213.

8. Vieštautas P. Lietuvių švietimo draugija „Rytas“. Vilnius: „Vilniaus varpo“ leidinys Nr. 2. 1927.

Gauta: 20130111

Parengta spaudai: 20130809

\section{Aldona VASILIAUSKIENE}

\section{THE LITHUANIAN "RYTAS" SOCIETY OF EDUCATION IN 1939-1940}

\section{S u m m a r y}

At the beginning of the 20th century "Žiburys", “Saulë" and "Rytas" societies, which had been set up in Suvalkija, Aukštaitija and Vilnius regions of Lithuania, performed imposing educational tasks and considerably contributed to raising Lithuanians' religious and national awareness. Naturally, these organizations became important centres unifying the Lithuanian Catholic intellectual movement.

The Lithuanian "Rytas" society of education (hereafter the "Rytas") was registered in Petrapilis on November 29, 1912. Its aim was to educate the Lithuanian population of the Vilnius County according to the lines of the teachings of the Roman Catholic Church. On January 31, 1913, the constituent assembly of the society took place on the premises of the parsonage of the All Saints church in Vilnius. Thus, the "Rytas" has celebrated its centenary on January 31,2013. The jubilee prompts the necessity to correct the recurrent mistakes which 
have been dominant in the press and publications of some researchers on the activities of this organization. In particular, it concerns the suspension of the "Rytas" activities and the closure of this organization in 1938, ignoring its endeavours to intensify its activity in 1939 and continue it until 1940 when the society was closed down by the soviet occupants. Therefore, the article offers a more extensive picture of the "Rytas" chronology highlighting the facts concerning the "Rytas" activities during the period of 1939-1940, which have been often overlooked by other researchers.

Some time before the Vilnius town storastija suspended the functioning of the "Rytas" society on January 29, 1938, and the Vilnius voivod closed it down a month later on February 28, 1938, some symptoms of the targeted destruction of this Lithuanian centre were quite evident, as since its very inception the "Rytas" society became an object of discord, which subsequently turned into an object of hatred. For instance, while still 95 Lithuanian libraries set up by the "Rytas" were functioning at the beginning of 1936, 82 of them were closed down by the Polish authorities in the course of 8 months. Out of a large number of schools only as many as two were left (only one school remained in 1937).

In the evening of November 25, 1936, a search was made in the "Rytas" office, its cash book and other documents were taken away (they were returned only in 1939 by new authorities).

The persistent efforts of the management board members of the "Rytas" produced some positive results, which were also conditioned by the political shifts of that time. On May 20, 1939 the ban on the activities of the "Rytas" society was lifted and on June 6 its property was given back. Unfortunately though, it entailed big debts.

The "Rytas" immediately undertook to restore its functions: it appealed to the Balstoge voivod asking it to revoke the ban of the activities of the "Rytas" at the boarder land. It intensified the admission of new members, the creation of the "Rytas" centres in the countryside, the founding of reading-rooms and book-shops, though these steps were often hindered by various obstacles.

The "Rytas" forms of actions were endorsed: meetings, regional conferences, youth rallies, the days of the week (weeks devoted to cultural events and the fight against vices) and solemn days. The centre undertook the work of writing the plans and the scenario. A significant form of its activities in districts and centres consisted of organizing courses of instruction for the leaders of centres and heads of libraries. At the end of 1939 the "Rytas" society gained exceptional strength. On February 21, 1940, the minister of Internal Affairs endorsed the statute of the "Rytas" society and sanctioned its activities. On February 22, 1940 the "Rytas" society was inscribed No 9357 on the list of the Register of societies.

The "Rytas" society which had accomplished many good deeds fostering the awareness of Lithuanian identity in the Vilnija region and promoting cultural life, like all other Catholic organizations, was closed down by the soviet occupational authorities in the summer of 1940 .

PAGRINDINIAI ŽODŽIAI: Lietuvių švietimo draugija „Rytas“, „Ryto“ centro valdyba, posèdžiai, „Ryto“ istatai (statutai), Mečislovas Reinys, Krištapas Čibiras.

KEY WORDS: the Lithuanian "Rytas" society of education, the "Rytas" centre board, sittings, regulations of the "Rytas" (statutes), Mečislovas Reinys, Krištapas Čibiras.

Aldona VASILIAUSKIENE் - humanitarinių mokslų (istorija) daktarė, Lietuvių katalikų mokslo akademija; Lie-
tuvių, ukrainiečiu istorikų asociacijos prezidentė. Mokslinių interesų sritys: Lietuvių katalikų mokslo akademi-
jos bei jos narių gyvenimo ir veiklos tyrimai, religijos istorija, lietuvių ir ukrainiečių istoriniai kultūriniai ryšiai,
Šv. Bazilijaus Didžiojo ordino istorija. Adresas: A. Vivulskio g. 15-12, 03221 Vilnius. El. paštas aldona.vasiliaus-
kienee@gmail.com.

Aldona VASILIAUSKIENE - Doctor of the Humanities (History) at the Lithuanian Catholic Academy of Science; President of the Association of Lithuanian and Ukrainian Historians. Fields of research interests: studies of Lithuanian Catholic Academy of Science, as well as the life and activity of its members, the history of religion, Lithuanian-Ukrainian historical cultural contacts, the history of the Order of St. Basilius the Great. Address: A. Vivulskio g. 15-12, 03221 Vilnius. E-mail: aldona.vasiliauskienee@gmail.com. 